\begin{tabular}{|c|c|c|}
\hline Beitr. Ent. & Keltern & ISSN 0005-805X \\
\hline $\mathbf{5 5}(2005) 2$ & S. $319-361$ & 27.12 .2005 \\
\hline
\end{tabular}

\title{
Sciarid flies from Dominican Amber
}

\author{
(Diptera, Sciaridae)
}

With 21 figures

\section{Werner Mohrig and Frank Röschmann}

\begin{abstract}
Summary
Results from this investigation describe 20 new fossil species from Dominican amber and one new genus with fossil and one recent species from Africa. The species belong to the following 8 genera: Trichosia (subgenus Mouffetina [1]); Leptosciarella (subgenus Leptosciarella [1]), Cratyna (subgenus Cratyna [1]), Cratyna unplaced [2], Archicratyna gen. nov. [4], Chaetosciara [1], Bradysiopsis [1], Bradysia [3], Corynoptera [3] and Epidapus [4].

None of the species identified within the Dominican amber are identical with those from the Baltic and Saxonian (Bitterfeld) amber, however there are several identical genera such as Trichosia, Leptosciarella, Cratyna, Corynoptera and Epidapus. All species from the Dominican amber belong to recent genera or subgenera, whereas many species from the Baltic and Saxonian amber belong to extinct genera or subgenera. Furthermore, the species from the Dominican amber possess more modern features than those from the European amber. Surprisingly, the fossil sciarid fauna from the Dominican amber shows more similarities to the recent fauna of the Holarctic region than to the recent fauna of Central and South America.
\end{abstract}

\section{Zusammenfassung}

Das Ergebnis der nachfolgenden Untersuchung ist die Neubeschreibung von 20 fossilen Arten aus Dominikanischen Bernstein und einer neuen Gattung mit fossilen und einer rezenten Art aus Afrika. Die Arten können 8 Gattungen zugeordnet werden: Trichosia (Subgenus Mouffetina [1]); Leptosciarella (Subgenus Leptosciarella [1]), Cratyna (Subgenus Cratyna [1]), Cratyna unplaziert [2], Archicratyna gen. nov. [4], Chaetosciara [1], Bradysiopsis [1], Bradysia [3], Corynoptera [3] und Epidapus [4].

Keine Art aus dem Dominikanischen Bernstein ist identisch mit Arten aus dem Baltischen bzw. dem Sächsischen (Bitterfeld) Bernstein, gehören aber zu gemeinsamen Gattungen wie Trichosia, Leptosciarella, Cratyna, Corynoptera and Epidapus. Alle Arten vom Dominikanischen Bernstein gehören zu rezenten Gattungen, während viele Arten vom Baltischen und Sächsischen Bernstein ausgestorbenen Gattungen bzw. Untergattungen repräsentieren. Ausserdem ist die Merkmalsausprägung moderner als bei den Arten aus Europäischem Bernstein. Erstaunlich ist weiterhin, dass die fossile Sciaridenfauna aus dem Dominikanischen Bernstein mehr Ähnlichkeiten mit der rezenten Fauna der Holarktischen Region als mit der rezenten Fauna von Mittel-und Südamerika aufweist.

\section{Key words}

Sciaridae, Dominican Amber 


\section{Introduction}

Inventory studies of the species of a given area are the fundamental basis for every zoogeographic or palaeozoologic analysis. In the case of sciarid faunas, there is little detailed information for all zoogeographic regions at present, except the Palaearctic Region, which has more than 800 well documented species and is much better known than any other region (MenZel \& Mohrig 2000). In a recent paper we investigated the extant sciarid fauna of Hispaniola as the comparative basis for studies of sciarids fossilized in Miocene amber from the Dominican Republic (Mohrig et al. 2004). The fairly young age of this amber requires that a sound knowledge of the extant sciarids of the Dominican Republic is known. This way, accurate comparison between the extant and extinct faunas can be made, even if only at generic level.

The sciarids or black fungus gnats are numerically one of largest families of Diptera and appear frequently in samples of wood biocoenosis (Menzel \& Mohrig 2000).

Larvae and adults are numerous in habitats with soil rich with decaying roots, leaves or rotten wood attacked by fungi. Therefore, members of Sciaridae are also fairly common in amber (SChumann \& Wendt 1989). Despite the frequent presence and well preserved state of Sciaridae in amber, the number of reported fossil species remains relatively low. Recently the type material of Meunier (1904) from Baltic amber was revised according to the contemporary taxonomical concept (Mohrig \& Röschmann 1994). The approximately two hundred fossil specimens of the type series belong to 22 species of 5 recent genera. At present, 41 fossil species from European amber have been exactly identified. For the Baltic amber (35-50 My [million years]), 23 species are registered and from the younger Bitterfeld or Saxonian amber (18-23 My), 32 species are known (MoHRIG \& Röschmann 1994; Röschmann \& Mohrig 1993, 1994a, 1994b, 1995a, 1995b, 1995c). With the exception of one species, they belong to the recent genera Trichosia, Leptosciarella, Cratyna, Epidapus, Corynoptera and Lycoriella. The genus Succinosciara Mohrig \& Röschmann, 1995 with one species is known only from Saxonian amber. Fourteen species of the older Baltic amber are identical with species of the much younger Saxonian amber. If the age of Saxonian amber has been correctly estimated, than we must assume that during the Tertiary period the sciarid species lived in stable conditions and underwent only a slow evolution. This suggests that the life span of an insect species could be at least 15 million years (Röschmann 1997). In comparison with the recent sciarid fauna, it is evident that morphological characteristics can persist for a period of about $40 \mathrm{My}$, and therefore, it is relatively easy to recognise the amber species as members of recent genera. Most of them belong to genera with a recently holarctic distribution such as Corynoptera (11 species), Trichosia/Leptosciarella (18 species) and Lycoriella (3 species). The genera Epidapus (3 species) and Cratyna (2 species) are cosmopolitan.

The Dominican amber is considerably younger than the Baltic amber and is probably formed from the legume Hymenaea. It was found in sedimentary rock and could be re-deposited and not autochthon of origin. The amber pieces originated from different mining sites in an area of various altitudes about $30 \mathrm{~km}$ north-east of Santiago. The Dominican amber is of Miocene origin with an estimated age of approximately 20-23 My (Brouwer \& Brouwer 1982; Grimaldi 1995) and therefore comparable in the level of faunistic elements with the Saxonian amber of Germany. Undetermined samples 
of sciarids in Dominican amber have been reported by PoInaR (1992). This paper is devoted mainly to the description of species of this sample, its relation to the Baltic amber fauna and the comparison with the recent established sciarid fauna of different zoogeographic regions.

\section{Material, Methods and Acknowledgements}

The amber pieces were received mainly from the collection of PoINAR, Oregon State University Corvallis, Oregon, as well as samples from the American Museum of Natural History New York and the British Museum of Natural History London.

For taxonomic studies of fossil sciarids only males are suitable, because the contemporary systematic is based exclusively on males. Females are impossible to identify according to the present knowledge of taxonomy at the species level. Furthermore, only amber pieces are usable in which the male is in such a position that the body in lateral view is in the same level as the taxonomically important hypopygium in ventral view. Unfortunately, this means that only a certain part of the fossiliferous specimens can be selected for exact determination. For microscopic observation the amber pieces were cut down to a thickness of about 2-3 mm, with one side as close as possible to the embedded specimen, using a hobby Globular saw. Then the amber pieces were carefully ground down further with fine sand paper until contact with a body part of the specimen was made (preferably cutting away part of a leg or antennae). Finally, the surface was polished with soft leather. Before examination, the amber pieces were put in paraffin oil for several days (in some cases under vacuum in an exsiccator). During this time the paraffin oil penetrated through the opened appendage, drove out the enclosed air and made the specimen transparent for microscopic examination. The specimens were studied and drawn under cover slips on a slide in a drop of paraffin oil. After examination the amber pieces were placed in a mixture of xylene and Canadian balsam for half an hour and finally included in Canadian balsam on slides with cover glass.

In the assessment of finer morphological structures (shape of antennae, palpi or thickness of gonostyles or legs) it is important to note that in the process of inclusion of a sciarid specimen it is initially sealed to the surface of fresh resin. Over time, it will begin to dry out and become sealed within subsequent drops of resin, so that lesser sclerotized structures often become wrinkled. Unwrinkled structures as hairs or bristles may appear larger in a microscope and surfaces may appear more coarse than in reality. Morphological terms, abbreviations for structures and diagnoses of genera and subgenera follow Menzel \& Mohrig 2000 and Mohrig et al. 2004).

We are much indebted to Dr. George Poinar, Department of Entomology, Corvallis, Oregon State University, who sent us many inclusions from his collection, and to Dr. David Grimaldi of American Museum of Natural History, New York, who kindly arranged not only the loan of amber, but also a large Malaise trap material of recent sciarids from the Dominican Republic for comparable studies. Finally, we would also like to acknowledge the efforts of Dr. EDwin Cooper, University of California, Los Angeles for improving the English of this manuscript.

Systematic palaeontology

\section{Order Insecta}

Family Sciaridae BILlBERG, 1820

Genus Trichosia WinnerTZ, 1867

Type species: Trichosia splendens WinnerTZ, 1867, from Rippoldsau/Schwarzwald, Germany. 
The genus Trichosia is distributed with about 20 recent species found only within the Holarctic region. Nine fossil species are known from the Baltic and the Saxonian amber (Mohrig \& Röschmann 1994; Röschmann \& Mohrig 1995a, 1995b). Only Trichosia meunieri (CoCKerell, 1910) belongs to the recent subgenus Trichosia s. str., whereas the other species belong to the fossil subgenera Palaeotrichosia Mohrig \& Röschmann (6 species) and Archaeosciara Mohrig \& Röschmann (2 species).

The recent subgenus Mouffetina FreY, 1942 contains four species, three of them are distributed only in the Palearctic region, whereas one (T. filispina Menzel \& Mohrig, 1997) has a northern Holarctic distribution.

\section{Subgenus Mouffetina FreY, 1942}

Type species: Plastosciara pulchricornis EDwARDs, 1925, Letchworth, Great Britain.

\section{Trichosia (Mouffetina) nova sp. n. $\dagger$}

(Fig. 1a-e)

\section{Description:}

$\sigma^{x}$. Head. Globular, eyes long setose (twice as long than the diameter of ommatidia), eye bridge complete, 3 facets wide. Antennae sixteen-segmented, with rounded pedicel and a shorter scape, scape with 3 longer bristles; flagellar segments short and strong, not elongate to the tip, with distinct necks; 4 . flagellomere about 1.2 times longer than wide, the basal part (node) not densely setose and half of the length of the diameter. Palpi reduced 2-3-segmented (mostly two-segmented), basal segment with fairly long sensillae and 1-2 bristles, short club-shaped; 2nd segment narrow and as long as the basal segment (fused with the third) or short globular; labelli large. Prefrons with few hairs, clypeus bare.

\section{Thorax:}

Mesonotum with long central hairs; lateral and praescutellar hairs not stronger; scutellum with about 6 longer marginal bristles and short hairs on the surface; posterior pronotum with 2-4 short hairs; antepronotum with 3-4 longer hairs, prethoracal episternite with 2-3 hairs; other pleural sclerites bare. Wings hyaline, with short and fine microtrichia, venation the same as in modern species; $\mathrm{R} 1=3 / 4 \mathrm{R}$, joining the $\mathrm{C}$ before the base of M-fork; R5 long and curved backwards, only distally with 1-2 ventral macrotrichia; C $=2 / 3 \mathrm{w} ; \mathrm{y}=\mathrm{x}$, without macrotrichia; posterior wing veins distinct; $\mathrm{M} 1=3 / 4$ length, $\mathrm{M} 2$ half of length, $\mathrm{Cu} 1 \mathrm{a}$ and $\mathrm{Cu} 1 \mathrm{~b}$ only distally with 1-3 macrotrichia (without any rarely); fork of $\mathrm{M}$ shorter than $\mathrm{M}$-stem; Cu1-stem somewhat shorter x. Halteres darkened, short club-shaped and sparsely setose. Coxae and legs normally thin, not elongated or shortened; fore tibia without spine-like bristles within the moderately long ground hair, with one long and thin apical spur, at the inner apex with a weak irregular patch of bristlelike hairs; spurs of mid and hind tibia equal, thin and longer than the diameter of the apex; the hind tibiae with a posterior row of fine spines, not sharply differed from the long ground hair, the apical spine-wreath very weak. Claws untoothed, long and slightly curved. 


\section{Abdomen:}

Tergal and sternal sclerites fairly dense and long setose. Hypopygium with a broad vshaped ventral base without any differentiation; gonocoxites long, the inner ventral border fairly long setose and the ventro-apical megaseta well developed; gonostyles prolong, apically curved, with 6 equal short apical spines and 2-3 longer subapical bristles; tegmen trapezoid; aedoeagus not visible. Body length: $2.8 \mathrm{~mm}$.

\section{Material:}

Amber from Santiago Province as locus typicus, Dominican Republic.

Holotype. $1{ }^{\star}$, Reg.-Nr. D.-A. Sci. 4 (coll. Poinar). Specimen in best condition, side view, hypopygium in ventral position.

Paratypes. 1 đ , Reg.-Nr. D.-A. Sci. 5 (coll. PoinAR), side view, hypopygium good visible by reorientation of slide; $1 \sigma^{\star}$, Reg. Nr. D.-A. Sci. 6 (coll. Poinar), dorsal view, hypopygium very well visible; 1 ๙ ${ }^{\star}$, Reg.-Nr. D.-A. Sci. 7 (coll. PoInar), dorsal view, hypopygium well visible; $1 \sigma^{*}$, Reg.-Nr. D.-A. Sci. 8a (coll. Poinar), dorsal view, hypopygium very well visible; 1 , , Reg.-Nr. D.-A. Sci. 8 b (coll. Poinar), side view, in very well conditions; $2 \sigma^{\star} \sigma^{\star}$, coll. Mohrig (from coll. Poinar), side view, legs more or less missing, hypopygium in good positions; all from mines near Santiago, specific locality unknown; $1 \sigma^{\star}$, coll. AMNH, Santiago Province, mines near La Toca/Palo Quemado, purchased from J. Brodzinsky 1988, AMNH no. DR-2-2; 1 `, coll. AMNH, Santiago Province, mines near La Toca/Palo Quemado, purchased from J. BrodzInsky, AMNH no. DR-579; 1 ๙ , specific locality unknown, purchased from J. WunderLich 1989, AMNH no. W-DR 61, side view, all very good in all details.

\section{Remarks:}

The species belongs to the genus Trichosia, subgenus Mouffetina, through macrotrichia on $\mathrm{M}$-fork and at the tip of $\mathrm{Cu} 1$, long $\mathrm{R}$, hairs on posterior pronotum, two-segmented palpi and especially through the shape and arrangement of spines on the gonostyles. The new species is closely related to the two recent palearctic species Trichosia $(M$.) pulchricornis (Edwards, 1925) and T. (M.) filispina Menzel \& MoHrig, 1997. Other similarities between the species include a fairly long tibial ground hair, a weak spine row on hind tibiae, long and slender tibial spurs and the prolonged, apically curved gonostyles with few short and equal spines at the tip.

\section{Genus Leptosciarella Tuомкоокі, 1960}

Type species: Sciara elegans Winnertz, 1867 [= Sciara scutellata StAeger, 1840], from Denmark.

The genus Leptosciarella encloses at present about 50 recent species and is divided into five subgenera. Leptosciarella s. str. with about 30 species is primarily Holarctic distributed, with a few species also in Central America. This subgenus is well characterised through the hawk beak -like apical tooth of the mostly prolonged gonostyles with short awl-like spines above it, hairs on posterior pronotum, large irregular patch of bristles at the tip of the fore tibiae and macrotrichia on the posterior wing veins, which is present in most species. The subgenus Protosciarella Mohrig, 2003 is distributed in Central and South 
America. The other subgenera - Hirtipennia Mohrig \& Menzel, 1997, Trichosiopsis Tuomikoski, 1960 and Leptospina Mohrig \& Menzel, 1997 - are distributed only in the eastern and northern Palearctic region.

Nine species are described from the European amber (Baltic and Saxonian), all belong to the recent subgenus Leptosciarella (Mohrig \& Röschmann 1994; Röschmann \& Mohrig 1995a and 1995b). As in modern species, only a portion of them (four to be exact) show macrotrichia on the posterior wing veins. The awl-like spines at the tip of the gonostyles as a modern differentiation are displayed by only three species, whereas the other species have short bristles at the tip above the tooth as in Protosciarella. The species of Leptosciarella are a very common and characteristic part of the fossil fauna of the Baltic amber.

\section{Subgenus Leptosciarella Tuомікозкі, 1960 s. str.}

Type species: Sciara elegans Winnertz, 1867 [= Sciara scutellata StAeger, 1840], from Denmark.

\section{Leptosciarella (Leptosciarella) manifesta sp. n. $\dagger$}

(Fig. 2a-e)

\section{Description:}

$0^{x}$. Head. Globular-ovoid, eyes long setose (twice as long than the diameter of ommatidia), eye bridge complete, 3-4 facets wide. Antennae sixteen-segmented, with rounded pedicel and a shorter scape; flagellar segments long and somewhat elongated to the tip, with distinct long necks; 4. flagellomere about 2.5 times longer than wide, basal part fairly dense, bristle-like and longer than the diameter setose. Palpi 3-segmented, basal segment with fairly short sensilla and 3-4 bristles, short club-shaped; 2 nd. segment short, 3rd. segment narrow and as long as the basal segment; labelli large. Prefrons with few hairs.

\section{Thorax:}

Mesonotum with long central, lateral and prescutellar hairs; scutellum with 2 stronger marginal bristles and short hairs on the surface; posterior pronotum bare. Wings hyaline, with short and fine microtrichia, venation the same as in modern species; R1 somewhat shorter R, joining the $\mathrm{C}$ before the base of $\mathrm{M}$-fork; R5 distally curved forwards joining the $\mathrm{C}$, without ventral macrotrichia; $\mathrm{C}=2 / 3 \mathrm{w} ; \mathrm{y}=\mathrm{x}$, without macrotrichia; posterior wing veins distinct, without macrotrichia. Halteres short club-shaped and sparse setose. Coxae and legs normally thin, not elongated or shortened; fore tibia without spine-like bristles within the short ground hair, with one long and thin apical spur, at the inner apex with a large irregularly patch of bristle-like hairs; spurs of mid and hind tibia equal, thin and longer than the diameter of the apex; the hind tibiae with a posterior row of strong spines; the apical spine-wreath well developed. Claws untoothed, long and slightly curved. 


\section{Abdomen:}

Tergal and sternal sclerites fairly dense, long and fine setose. Hypopygium on ventral base without any differentiation; gonocoxites long, the inner ventral border fairly short setose and the ventro-apical megaseta well developed; gonostyles apically narrowed, with a strong hawk-like apical spine and few short awl-like spines above; tegmen rectangular; aedoeagus not visible. Body length: $2 \mathrm{~mm}$.

\section{Material:}

Amber from the Dominican Republic, Santiago Province as locus typicus, specific locality unknown.

Holotype: 1 ๑, AMNH, Reg.-Nr. 11644 B. Specimen in ventral view, hypopygium in excellent ventral position.

Paratype: $1 \sigma^{\star}$, Reg.-Nr. D.-A. Sci. 9 (coll. Poinar), side view, without legs, hypopygium in good position.

\section{Remarks:}

The species is a typical representative of Leptosciarella s. str. by the strong hawk-like tooth with short awl-like spines above at the tip of the gonostyles. The lack of hairs on posterior pronotum and no macrotrichia on the posterior wing veins show also some species from Baltic amber (Mohrig \& Röschmann 1994, Röschmann \& Mohrig 1995a, b) as well as Leptosciarella nudivenosa MoHrig \& Röschmann, 2004 from the recent sciarid fauna of the Dominican Republic.

\section{Genus Cratyna WINNERTZ, 1867}

Type species: Cratyna atra WinnerTz, 1867, from Germany.

The identity of Cratyna atra WinnerTz with Pseudosciara pictiventris KIEFFER as the type species of Plastosciara Berg, 1899 (Menzel \& Mohrig 1998, 2000) confirmed the genus name Cratyna Winnertz, 1867 for a group of species, redefined by Tuомiкoski (1960) as a concept of Plastosciara including the genera Termitosciara Schmitz, 1915, Peyerimhoffia Kieffer, 1903 and Spathobdella Frey, 1948).

Well known and clearly defined are the species belonging to the subgenus Spathobdella [type species $C$. nobilis (WINNERTz)], distributed only within the Holarctic region. One fossil species from this subgenus is known from the Saxonian amber (Cratyna archaica Röschmann \& Mohrig), representing a more ancestral type.

Well defined are also the subgenera Cratyna s. str. with species related to the type C. atra Winnertz, and the subgenus Peyerimhoffia with the type species C. vagabunda (WinnerTz) within the Palearctic region.

Cratyna s. str. is characterised by short and thick palpi with the tendency to reduction to two- or one-segmented, short gonocoxites with short and thick gonostyles without an apical tooth, but with some hyaline spines (two pairs in most of all species), a rounded tegmen with a short thumb-like structure apically and a semiglobular line in the middle, an irregular patch of bristles at the tip of fore tibiae, hairs on posterior pronotum in most cases and more than two marginal bristles on the scutellum. Cratyna s. str. is worldwide 
distributed, but it seem so that the greater number of species are present in the southern hemisphere (Lane 1960 from South America; Hippa et al. 1998 from South Asia, Mohrig 1999 from the Australian region). One fossil species is described from the Saxonian amber in female sex as Plastosciara keilbachi Röschmann \& MoHrig, 1994.

\section{Subgenus Cratyna WINNERTZ s. str.}

Type species: Cratyna atra WinnerTZ, 1867, from Germany.

\section{Cratyna (Cratyna) tempestiva sp. n. $\dagger$}

(Fig. 3a-h)

\section{Description:}

${ }^{\star}$. Head. Globular, eyes sparse setose, eye bridge complete, 3 facets wide. Antennae sixteen-segmented, with rounded pedicel and a shorter scape; flagellar segments short and strong, with distinct necks; 4 . flagellomere about 1.8 times longer than wide, basal part dense and somewhat shorter than wide setose. Palpi three-segmented, basal segment with fairly long sensilla and 2 bristles, one of them longer; 2 nd. segment short and rounded, 3rd. segment narrow and as long as the basal segment; labelli large. Prefrons with few hairs, clypeus bare.

\section{Thorax:}

Mesonotum with long central hairs; lateral and prescutellar hairs stronger; scutellum with 4 strong marginal bristles and few short hairs on the surface; posterior pronotum with 3-4 short hairs; antepronotum with 3 hairs, one longer, prethoracic episternit with 5-6 hairs; other pleural sclerites bare. Wings hyaline, with short and fine microtrichia, venation the same as in modern species; R1 $=2 / 3 \mathrm{R}$; R5 only distally with dorsal and ventral macrotrichia; $C=2 / 3 \mathrm{w}$; y somewhat longer $\mathrm{x}$, with 1-2 macrotrichia; posterior wing veins distinct, without macrotrichia; fork of $M$ fairly short and narrow, shorter than M-stem; Cu1-stem very short. Halteres short club-shaped and sparsely setose. Coxae and legs normal, not elongated or shortened; fore tibia with few short spine-like bristles within the short ground hair and with one apical spur, at the inner apex with an irregularly patch of bristle-like hairs; spurs of mid and hind tibia equal and long, longer than the diameter of the apex; the hind tibiae with a posterior row of spines and a distinct apical spine-wreath. Claws untoothed, curved.

\footnotetext{
Abdomen:

Tergal and sternal sclerites fairly dense and long setose. Hypopygium with a broad closed ventral base without any differentiation; gonocoxites shortened and fairly strong, the inner ventral border sparse setose and the ventro-apical megaseta well developed; gonostyles swollen, short and thick, the inner side flat excavated and with 4 hyaline spines, one pair on the apex and the second subapically at the end of excavation; tegmen rounded, with an inner semiglobular structure and a short thumb-like appendix apically; aedoeagus not visible. Body length: $2.2 \mathrm{~mm}$.
} 


\section{Material:}

Amber from Santiago Province as locus typicus, Dominican Republic.

Holotype. $1 \sigma^{\star}$, Reg.-Nr. D.-A. Sci. 1 (coll. Poinar). Specimen in best condition, side view, hypopygium in ventral position.

Paratypes: $1 \sigma^{\star}$, Reg.-Nr. D.-A. Sci. 2 (coll. Poinar), dorsal view, hypopygium in ventral position; $1 \sigma^{*}$, Reg.-Nr. D.-A. Sci. 3 (coll. Poinar), side view, hypopygium well visible by perepreparation of the slide; $1 \sigma^{\star}$, coll. Mohrig (from coll. Poinar), side view, hypopygium in ventral position; all same locality.

\section{Remarks:}

The species is a typical representative of the subgenus Cratyna s. str. by the short and strong gonocoxites and the short and swollen gonostyles, apically/subapically with 4 hyaline spines in two pairs. In the shape of gonostyles and arrangement of spines it is similar to recent species Cr. subalpina Mohrig \& Mamaev, 1990 (Palearctic region), Cr. curaosi Lane, 1960 (Neotropic region), and Cr. fumoalata Mohrig \& Röschmann from the recent sciarid fauna of the Dominican Republic. Three-segmented palpi are common also in recent species, although they show in majority two- or on-segmented palpi. All other characteristics of the amber species do not differ in any way from the modern species of this genus.

\section{Unplaced species of Cratyna}

\section{Cratyna villosoantennata sp. n. $\dagger$}

(Fig. 4a-d)

\section{Description:}

$0^{\star}$. Head. Globular, eyes sparse and short setose, eye bridge complete, 4 facets wide. Antennae sixteen-segmented, with rounded pedicel and a shorter scape; flagellar segments fairly long and strong, with fairly short necks; 4 . flagellomere about 2 times longer than wide, basal part very dense and as long as wide setose. Palpi three-segmented, basal segment with 2 or 3 bristles, 3rd. segment narrow and somewhat longer than the second segment; labelli large.

\section{Thorax:}

Mesonotum with long and dark central hairs; lateral and prescutellar hairs stronger; scutellum with 4-6 strong marginal bristles and few short hairs; posterior pronotum with 4 or 5 hairs. Wings brownish, with short and fine microtrichia, venation the same as in modern species; R1 longer 1/2 R; R5 only distally with dorsal and ventral macrotrichia; $\mathrm{C}=2 / 3 \mathrm{w} ; \mathrm{y}=\mathrm{x}$, without macrotrichia; posterior wing veins distinct $(\mathrm{M}$ weaker than $\mathrm{Cu} 1$ ), without macrotrichia; fork of $\mathrm{M}$ narrow, somewhat shorter than $\mathrm{M}$-stem; Cu1stem very short. Halteres short club-shaped. Coxae and legs slender, not elongated or shortened; fore tibia with few short spine-like bristles within the short ground hair and with one strong apical spur, at the inner apex with a small irregular patch of bristles; spurs of mid and hind tibia equal and long, much longer than the diameter of the apex; the hind tibiae with a strong posterior row of spines and a distinct apical spine-wreath. Claws untoothed, curved. 


\section{Abdomen:}

Tergal and sternal sclerites fairly dense and long setose. Hypopygium with a v-shaped ventral base without any differentiation; gonocoxites long, the ventro-apical megaseta well developed; gonostyles fairly short, narrowed to the tip and slightly curved, with a apical group of 5-6 equal and fairly long hyaline, bristle-like spines; tegmen rounded; aedoeagus not visible. Body length: $2.2 \mathrm{~mm}$.

\section{Material:}

Amber from Santiago Province as locus typicus, Dominican Republic.

Holotype. $1 \sigma^{\star}$, Reg.-Nr. D.-A. Sci. 16 (coll. Poinar), Oregon, USA; specimen in good condition, but not well transparent; side view, hypopygium in ventral position.

\section{Remarks:}

The species is characterised by the irregular patch of bristles at the tip of fore tibiae, strong and dense setae on antennal segments, strong setae on the scutellum, few setae on posterior pronotum and the apical group of 5-6 equal and fairly long hyaline, bristle-like spines on gonostyles. The species is in all details similar to the modern species of the genus Cratyna. It differs from the above described species in the arrangement of the spines at the tip of the gonostyles. Perhaps it belongs together with the following Cr. interposita into the relationship of the recent palearctic species C. uliginosa (LENGERSDORF, 1929), which is similar in the arrangement of spines at the tip of gonostyles and three-segmented palpi.

\section{Cratyna interposita sp. n. $\dagger$}

(Fig. 5a-e)

\section{Description:}

${ }^{\star}$. Head. Globular, eyes fairly long setose, eye bridge complete, 4 facets wide. Antennae sixteen-segmented, with rounded pedicel and a shorter scape; flagellar segments fairly short and strong, with distinct necks; 4. flagellomere about 2 times longer than wide, basal part dense, stand up and somewhat shorter than wide setose. Palpi short, threesegmented, basal segment with 1 bristle; 2 nd. segment short and Globular, 3rd. segment narrow and as long as the basal segment; labelli large.

\section{Thorax:}

Mesonotum with long central hairs; lateral and prescutellar hairs strong; scutellum with 4-6 strong marginal bristles and few short hairs; posterior pronotum setose; antepronotum with few hairs, one or two strong, prethoracic episternit shorter setose; other pleural sclerites bare. Wings broad, hyaline, with short and fine microtrichia, venation the same as in modern species; $\mathrm{R} 1=2 / 3 \mathrm{R}$; $\mathrm{R} 5$ only distally with dorsal and ventral macrotrichia; $\mathrm{C}=2 / 3 \mathrm{w}$; $\mathrm{y}$ somewhat longer $\mathrm{x}$, without or with 1-2 macrotrichia; posterior wing veins distinct, without macrotrichia; Cu1-stem very short. Halteres short club-shaped and sparse setose. Coxae and legs normal, not elongated or shortened; fore tibia with few short spine-like bristles within the short ground hair and with one apical spur, at the inner apex with an irregularly patch of bristle-like hairs; spurs of mid and hind tibia equal and long, much longer than the diameter of the apex; the hind tibiae with a posterior row of spines and a distinct apical spine-wreath. Claws untoothed, slightly curved. 


\section{Abdomen:}

Tergal and sternal sclerites fairly dense and long setose. Hypopygium with a v-shaped ventral base without any differentiation; gonocoxites fairly long, the ventro-apical bristle well developed; gonostyles short and somewhat swollen, apically strong narrowed and with 2 thin and curved spines; tegmen and aedoeagus not visible. Body length: $2.4 \mathrm{~mm}$.

\section{Material:}

Amber from Santiago Province as locus typicus, Dominican Republic.

Holotype. $1 \sigma^{\star}$, BMNH Pal. PI II 370(1), London, purchased by McCallum, Marcus 1994. Specimen in good condition, side view, hypopygium in ventral position, gonostyles somewhat sloping positioned.

Paratype: $1 \sigma^{\star}$, AMNH no. OR-10-828; Dominican Amber, Dominican Republic, locality unknown. Body in very good condition, hypopygium damaged.

\section{Remarks:}

The species is characterised by the short three-segmented palpi with only one bristle, the shape of flagellomeres with distinct necks and an erect hair, the graceful legs and short and somewhat swollen gonostyles, apically strong narrowed and with 2 thin and curved spines. According to the general features, this species belongs to the genus Cratyna.

\section{Genus Archicratyna MoHRIG gen. n.}

Type species: Archicratyna zimbabweensis MoHrig sp. n.

\section{Diagnosis:}

$0^{\star}$. Head. Globular, dark; eye bridge complete, antennae sixteen-segmented, with rounded pedicel and shorter scape; palpi long, 3-segmented, basal segment prolonged, with short sensilla and few bristles. Posterior pronotum bare. Wings pale, posterior wing veins mostly without macrotrichia. Haltere short club-shaped and sparse setose. Coxae and legs normally, not prolonged or shortened; fore tibia without short spine-like bristles within the short ground hair and with one apical spur, at the inner apex with a irregular, unbordered patch of bristle-like spines; spurs of mid and hind tibia equal and longer than the diameter of the apex; the hind tibiae with a posterior row of spines and a distinct apical spine-wreath. Claws untoothed.

Hypopygium without ventral lobe; gonocoxites long, with one ventral megaseta at the tip; gonostyles prolonged, at the tip with a short awl-like tooth with a very fine roughly surface, surrounded by 5-6 longer and curved spines. tegmen simple and apically rounded, with a fairly large area of fine teeth, aedoeagus fairly long.

\section{Remarks:}

The new genus is based on the unique autapomorphic feature of the short awl-like tooth within longer apical spines. All other characteristics are plesiomorphic and place the genus in the ensemble of more ancient genera near Cratyna. 
Archicratyna zimbabweensis MOHRIG sp. n.

(Fig. 6a-e)

\title{
Description:
}

$\sigma^{7}$. Head. Globular, eyes fairly long; eye bridge complete, 3 facets wide. Antennae unicoloured brown; flagellomere long, with fairly long necks and a weak roughly surface; 4 . flagellomere about 3 times longer than wide, stand up and as long as wide setose. Palpi three-segmented, basal segment long, with 4-5 bristles; third segment narrow and as long as the basal segment.

\section{Thorax:}

Mesonotum with fairly short hair; lateral and prescutellar hairs not stronger; posterior pronotum bare. Wings somewhat brownish, on membrane with short and fine microtrichia; R1 = 2/3 R; R5 only with dorsal macrotrichia; $C=2 / 3 \mathrm{w} ; \mathrm{y}=\mathrm{x}$, with few macrotrichia; posterior wing veins distinct, without macrotrichia; $M$-fork fairly narrow; $\mathrm{Cu} 1$-stem shorter x. Halteres darkened, short club-shaped and sparsely setose. Coxae and legs not prolonged; fore tibia without spine-like bristles within the short ground hair, with one apical spur; at the inner apex with a irregularly patch of pale bristles; spurs of mid and hind tibia equal and longer than the diameter of the apex; the hind tibiae with a posterior row of spines and a distinct apical spine-wreath. Claws untoothed.

\begin{abstract}
Abdomen:
Tergal and sternal sclerites fairly long and finely setose. Hypopygium brownish, with a broad v-shaped ventral base without any differentiation; gonocoxites long, the inner ventral border fairly short setose and the ventro-apical megaseta well developed; gonostyles prolonged, apically curved and with 4 apical spines around a shorter tooth; tegmen rounded, with a central area of fine teeth; aedoeagus fairly long. Body length: $3 \mathrm{~mm}$.
\end{abstract}

\section{Material:}

One specimen from Zimbabwe, Africa, Matabeleland, Matopus National Park, Bombata Cave Road, 20³0'41'south, 28²5'37' east as locus typicus.

Holotype. $1 \sigma^{\star}, 12.3 .2000$, catch by net, leg. W. Mohrig (coll. Mohrig).

\section{Remarks:}

The species is characterised by the unicolour brown antennae with long flagellomeres, fairly long necks and a weakly rough surface, erect setae as long as the diameter of the basal node, three-segmented palpi and prolonged gonostyles, apically curved and with 4 apical spines around a shorter tooth. This new species from Southern Africa is the only one of recent members of the new genus. It is very similar to the following three fossil species from Dominican amber. 


\section{Archicratyna arcana sp. n. $\dagger$}

(Fig. 7a-g)

\section{Description:}

$\sigma^{*}$. Head. Globular, eyes long setose (twice the diameter of ommatidae), eye bridge complete, 3 facets wide. Antennae sixteen-segmented, with rounded pedicel and a shorter scape; flagellar segments long and strong, with fairly long necks and a strong roughly surface; 4. flagellomere about 2.4 times longer than wide, basal part stand up and longer than wide setose. Palpi three-segmented, basal segment long, with 2 bristles; 3rd. segment narrow and as long as the basal segment.

\section{Thorax:}

Mesonotum with fairly long central hairs; lateral and prescutellar hairs stronger; scutellum with 4 strong marginal bristles and few shorter hairs; posterior pronotum probably bare; antepronotum and prethoracic episternit with 5-6 longer hairs; other pleural sclerites bare. Wings somewhat brownish, with short and fine microtrichia, venation the same as in modern species; R1 = 2/3 R; R5 only with dorsal macrotrichia; $\mathrm{C}=2 / 3 \mathrm{w}$; $\mathrm{y}$ somewhat shorter $\mathrm{x}$, without macrotrichia; posterior wing veins distinct, without macrotrichia; fork of $\mathrm{M}$ short and fairly broad, shorter than M-stem; Cu1-stem fairly long, but shorter x. Halteres darkened, short club-shaped and sparse setose. Coxae and legs normally, not elongated or shortened; fore tibia without short spine-like bristles within the short ground hair and with one apical spur, at the inner apex with a small irregular patch of bristle-like hairs; spurs of mid and hind tibia equal and long, longer than the diameter of the apex; the hind tibiae with a posterior row of spines and a distinct apical spine-wreath. Claws untoothed, curved.

\section{Abdomen:}

Tergal and sternal sclerites fairly long setose. Hypopygium with a broad v-shaped ventral base without any differentiation; gonocoxites long, the inner ventral border sparsely setose and the ventro-apical megaseta developed; gonostyles elongate, curved apically and with 4 short apical spines around a very short finger-like tip; tegmen rounded; aedoeagus not visible. Body length: $3 \mathrm{~mm}$.

\section{Material:}

Amber from El Valle, Santiago Province as locus typicus, Dominican Republic.

Holotype. $1 \sigma^{\star}$, Reg.-Nr. D.-A. Sci. 17 (coll. Poinar). Specimen in best condition, side view, hypopygium in ventral position.

Paratype: $1 \sigma^{\star}$, Dominican Amber, Dominican Republic, El Valle, AMNH no. DR-556, New York, purchased from J. Brodzinky; ventral view, body in bad position, hypopygium well visible.

\section{Remarks:}

The species is characterised by the fairly long antennae (flagellomere 4 about 2.4 times longer than wide), the lack of macrotrichia on posterior wing veins, and elongate gonostyles, apically curved and with 4 short apical spines around a very short finger-like tip. The species is very similar in the shape of gonostyles and the arrangement of spines to 
the following described Archicratyna trichoarcana, but distinguished by the lack of macrotrichia on the posterior wing veins.

\section{Archicratyna trichoarcana sp. n. $\dagger$}

(Fig. 8a-g)

\section{Description:}

$\sigma^{\star}$. Head. Globular, eyes long setose (twice of the diameter of ommatidia), eye bridge complete, 3-4 facets wide. Antennae sixteen-segmented, with rounded pedicel and a shorter scape; flagellar segments strong, with fairly long necks and a strong roughly surface; 4. flagellomere about 2 times longer than wide, basal part stand up and very long setose. Palpi three-segmented, basal segment narrow, prolong, with 2 bristles; 3rd. segment narrow and as long as the basal segment.

\section{Thorax:}

Mesonotum with fairly long central hairs; lateral and prescutellar hairs stronger; scutellum with 4-6 strong marginal bristles and few shorter hairs; posterior pronotum with 4 hairs; antepronotum and prethoracal episternite with 5-6 short hairs; other pleural sclerites bare. Wings pale, with short and fine microtrichia, venation the same as in modern species; R1 = 4/5 R; R5 with dorsal and few ventral macrotrichia distally; $\mathrm{C}=$ 3/4 w; y somewhat shorter $\mathrm{x}$, without macrotrichia; posterior wing veins distinct, only $\mathrm{M}$-stem weak; fork of $\mathrm{M}$ in the whole, $\mathrm{Cu} 1 \mathrm{a}$ in the distal half and $\mathrm{Cu} 1 \mathrm{~b}$ at the end with macrotrichia; Cu1-stem shorter x. Halteres darkened, short club-shaped and sparse setose. Coxae and legs slender, $\mathrm{p}_{3}$ somewhat elongated; fore tibia without short spine-like bristles within the short ground hair and with one apical spur, at the inner apex with a irregular patch of bristle-like hairs; spurs of mid and hind tibia equal and long, longer than the diameter of the apex; the hind tibiae with a posterior row of spines and a apical spine-wreath. Claws untoothed, curved.

\section{Abdomen:}

Tergal and sternal sclerites fairly long setose. Hypopygium with a broad v-shaped ventral base without any differentiation; gonocoxites long, the inner ventral border sparse setose and the ventro-apical megaseta well developed; gonostyles elongate, curved apically and with 4 short apical spines around a short finger-like tip; tegmen and aedoeagus not visible. Body length: $3 \mathrm{~mm}$.

\section{Material:}

Amber from Santiago Province as locus typicus, Dominican Republic.

Holotype: $1 \sigma^{\star}$, Reg.-Nr. D.-A. Sci. 24 coll. Poinar, Oregon, USA; specimen in best condition, side view, hypopygium in ventral position.

\section{Remarks:}

The species is very similar to Archicratyna arcana and the following Archicratyna subarcana. It is distinguished mainly by the macrotrichia on the posterior wing veins. 
Archicratyna subarcana MoHRIg \& RöschmanN n. sp. $\dagger$

(Fig. 9 a-e)

\section{Description:}

$\sigma^{*}$. Head. Globular, eyes long setose (twice of the diameter of ommatidia), eye bridge complete. Antennae sixteen-segmented, with rounded pedicel and a shorter scape; flagellar segments long and strong, with fairly long necks and a strong roughly surface; 4. flagellomere about 2.8 times longer than wide, basal part stand up and longer than wide setose. Palpi three-segmented, basal segment long, with few bristles; 3rd. segment narrow.

\section{Thorax:}

Mesonotum with fairly long central hairs; lateral and prescutellar hairs strong; scutellum with 4 stronger marginal bristles and few shorter hairs; posterior pronotum setose. Wings pale, with short and fine microtrichia, venation the same as in modern species; R1 $=2 / 3 \mathrm{R} ; \mathrm{R} 5$ only with dorsal macrotrichia; $\mathrm{C}=2 / 3 \mathrm{w} ; \mathrm{y}=\mathrm{x}$, without macrotrichia; posterior wing veins distinct, without macrotrichia; $\mathrm{Cu} 1$-stem shorter $\mathrm{x}$. Halteres darkened, club-shaped with a fairly long stem and sparse setose. Coxae and legs normal, not elongated or shortened; fore tibia without short spine-like bristles within the short ground hair and with one apical spur, at the inner apex with a small irregular patch of bristle-like hairs; spurs of mid and hind tibia equal, long and fairly thin, longer than the diameter of the apex; the hind tibiae with a posterior row of spines and a distinct apical spine-wreath. Claws untoothed, curved.

\section{Abdomen:}

Tergal and sternal sclerites fairly long setose. Hypopygium with a broad v-shaped ventral base without any differentiation; gonocoxites long, the inner ventral border fairly long setose and the ventro-apical megaseta well developed; gonostyles narrow, elongate, curved apically and with 4 long apical spines around a shorter finger-like tip; tegmen rounded, aedoeagus not visible. Body length: $2 \mathrm{~mm}$.

\section{Material:}

Amber from Santiago Province as locus typicus, Dominican Republic.

Holotype: $10^{\star}$, Reg.-Nr. D.-A. Sci. 18 coll. Poinar, Oregon, USA; specimen in best condition, side view, hypopygium in ventral position.

Paratype: $1 \sigma^{\star}$, Dominican amber, coll. Mohrig (from coll. Poinar).

\section{Remarks:}

This species is similar to the above described Archicratyna arcana. It is visibly smaller in body size, the gonostyles are also narrower and the apical spines much longer.

\section{Chaetosciara FrEY, 1942}

(Notul. Ent., 22: 32,33)

Type species: Sciara estlandica Lengersdorf, 1929 
The genus is characterised by short flagellomeres with very short necks, three-segmented palpi with few bristles on the basal segment, an irregular patch of bristles at the tip of fore tibiae and a very characteristic intercoxal lobe on the ventral base of the hypopygium. We know only three eastern Palearctic species (Menzel \& Mohrig 2000), one species from the Dominican Republic (Chaetosciara gilva Mohrig \& Röschmann 2002) and two species from Papua-New-Guinea (Mohrig 1999). Some further species are mentioned for the Neotropic (two questionable, unverified species, Amorim 1992) and the IndoMalayan area (5 species, STEFFAN 1972 a, b). Fossil species were previously unknown.

\title{
Chaetosciara obsoleta Mohrig \& Röschmann n. sp. $\dagger$
}

(Fig. 10 a-e)

\section{Description:}

$\sigma^{x}$. Head. Globular. Eyes short setose, eye bridge complete, 4 facets wide. Antennae sixteen-segmented, with rounded pedicel and a shorter scape, scape with few hairs, one longer; flagellar segments short and strong, weakly prolonged to the tip, with short distinct necks; 4 . flagellomere about 1.8 times longer than wide, basal part dense and shorter than the diameter setose, between hairs long and curved sensory hairs; surface roughly. Palpi 3-segmented, basal segment with fairly long sensilla and 4-5 bristles, short clubshaped; 2nd. segment short ovoid, 3rd. segment narrow and twice as long as the second segment; labelli large. Prefrons with few hairs, clypeus bare.

\section{Thorax:}

Mesonotum with fairly short central hairs; some lateral and prescutellar hairs stronger; scutellum with 2 longer marginal bristles and short hairs on the surface; posterior pronotum bare; antepronotum and prethoracal episternite with 4-5 longer hairs; other pleural sclerites bare. Wings weakly brownish, with short and fine microtrichia, venation the same as in modern species; R1 = 2/3 R; R5 long and curved backwards joining the $\mathrm{C}$, only distally with 1-2 ventral macrotrichia; $\mathrm{C}=2 / 3 \mathrm{w} ; \mathrm{y}=\mathrm{x}$, without macrotrichia; posterior wing veins distinct, without macrotrichia; fork of $M$ shorter than $M$-stem; Cu1stem shorter x. Halteres darkened, short club-shaped and sparse setose. Coxae and legs normally thin, not elongated or shortened; fore tibia with few spine-like bristles within the short ground hair, with one long apical spur, at the inner apex with a large irregular patch of bristle-like hairs; spurs of mid and hind tibia equal and longer than the diameter of the apex; the hind tibiae with a posterior row of spines, the apical spine-wreath well developed. Claws untoothed, slightly curved.

\begin{abstract}
Abdomen:
Tergal and sternal sclerites fairly short setose. Hypopygium at the ventral base with a large intercoxal lobe, setose at the surface; gonocoxites long, the inner ventral border fairly short setose and the ventro-apical megaseta well developed; gonostyles prolonged, apically curved, with 3 long and equal apical spines and one long subapical bristle; tegmen trapezoid; aedoeagus not visible. Body length: $2.5 \mathrm{~mm}$.
\end{abstract}

\section{Material:}

Amber from Santiago Province as locus typicus, Dominican Republic. 
Holotype: $10^{\star}$, Reg.-Nr. D.-A. Sci. 10 (coll. Poinar). Specimen in best condition, side view, hypopygium in ventral position.

Paratype: $10^{\star}$, coll. Mohrig (from coll. Poinar), side view, hypopygium in good ventral position.

\section{Remarks:}

The species is a typical representative of Chaetosciara by the intercoxal lobe, short flagellomeres with short necks and a coarse surface, bare posterior pronotum, large irregular tibial patch and three long apical spines together with a long subapical whiplash hair. It is quite different from the recent Dominican species Chaetosciara gilva MoHrig \& Röschmann. From all known recent species, it is most similar to Ch. estlandica (LENGERsDorf, 1929), which is distributed in the mid and north-eastern parts of the Palearctic region.

\section{Genus Bradysiopsis Tuомікоsкі, 1960}

(Ann. Zool. Soc. "Vanamo”, 21 (4): 73, 74)

Type species: Lycoriella (Bradysiopsis) leucotricha Tuomıкоsкi, 1960 - Ann. Zool. Soc. "Vanamo", 21(4): 74, 75.

This genus is known with only three species, distributed within the Palearctic region (Menzel \& Mohrig 1998, 1999). It is characterized by having a bare posterior pronotum, long three-segmented palpi, short and fine hair of the mesonotum, 4 marginal bristles on scutellum, semiglobular bordered patch of bristles at the tip of fore tibiae, strong posterior wing veins and fairly simple gonostyles with an apical tooth and few subapical spines.

\section{Bradysiopsis repentina MoHRIg \& Röschmann n. sp. $\dagger$}

(Fig. $11 \mathrm{a}-\mathrm{e})$

\section{Description:}

$0^{\star}$. Head. Globular, eyes long setose (twice as long than the diameter of ommatidia), eye bridge complete, 3 facets wide. Antennae sixteen-segmented, with rounded pedicel and a shorter scape; flagellar segments long and thin, elongated to the tip, with distinct necks; 4. flagellomere about 4 times longer than wide, basal part fairly dense and as long as the diameter setose. Palpi long, 3-segmented, basal segment with 4-5 bristles, club-shaped; 2nd. segment Globular and half as long as the third segment; labelli large. Prefrons fairly dense and short setose.

\section{Thorax:}

Mesonotum with short and pale central hairs; some lateral and prescutellar hairs somewhat longer; scutellum with 2 longer marginal bristles and few short hairs; posterior pronotum bare; antepronotum and prethoracal episternite with 2-3 fine hairs; other pleural sclerites bare; katepisternum normally high. Wings hyaline, with short and fine microtrichia, venation the same as in modern species; $R 1=2 / 3 R$, joining the $C$ before the base of M-fork; R5 long and curved backwards before joining the C, only distally 
with 2-3 ventral macrotrichia; $C$ somewhat longer $1 / 2 \mathrm{w} ; \mathrm{y}=\mathrm{x}$, without macrotrichia; posterior wing veins strong, without macrotrichia; fork of $\mathrm{M}$ shorter than $\mathrm{M}$-stem; Cu1stem shorter x. Halteres darkened, short club-shaped and sparse setose. Coxae and legs distinctly elongated; fore tibia without spine-like bristles within the moderately long ground hair, with one long and thin apical spur, at the inner apex with an irregular patch of long hyaline bristle-like hairs; spurs of mid and hind tibia equal, thin and longer than the diameter of the apex; the hind tibiae with a double posterior row of strong spines within the fairly long ground hair, the apical spine-wreath strong. Claws untoothed, long and slightly curved.

\section{Abdomen:}

Tergal and sternal sclerites fairly dense and long pale setose. Hypopygium with a broad $\mathrm{v}$-shaped ventral base without any differentiation; gonocoxites long, the inner ventral border short setose and the ventro-apical megasea well developed; gonostyles prolonged, thin, with a fairly strong apical tooth and 3 subapical spines; tegmen and aedoeagus not visible. Body length: $3 \mathrm{~mm}$.

\section{Material:}

Amber from Santiago Province as locus typicus, Dominican Republic.

Holotype: $1 \sigma^{\star}$, Reg.-Nr. D.-A. Sci. 11 (coll. PoInAR). Specimen in good condition, side view, hypopygium in ventral position.

Paratype: $1 \sigma^{\star}$, (coll. Mohrig, from coll. Poinar), side view, hypopygium good visible, legs partly lacking.

\section{Remarks:}

The species is a representative of the Palearctic genus Bradysiopsis Tuомıкоsкi, 1960 by the typical shape and arrangement of the apical tooth and subapical spines of gonostyles. As in recent species, the mesonotum is strongly vaulted, the body hair short and pale, the flagellomeres very long, the basal segment of palpi with 4-5 bristles, the posterior wing veins strong and the hind tibiae show strong spine rows and a strong apical spine-wreath. The position of the katepisternum is not so caudally directed as in recent species. The gonostyles are as in the recent species Bradysiopsis vittata (MEIGEN, 1830) and hardly distinguishable.

\section{Genus Bradysia WinNERTZ, 1867}

(Monogr. Sciarinen: 180)

Type species: Bradysia angustipennis WinnerTz, 1867 - Monogr. Sciarinen: 180-181.

Bradysia is one of the largest genera of sciarids with more than 210 Palearctic species and about 240 species in other zoogeographic regions, mostly within the Nearctic region and the Oriental-Australian area. The feature of this genus is quite heterogeneous in the shape of gonostyles with the arrangement of teeth and spines, the hair of antennal flagellomeres and the appearance of intercoxal differentiation. But despite the heterogeneity, the species of Bradysia show one excellent apomorphic characteristic - a strong comb of short spine-like bristles at the tip of the inner side of fore tibiae, whose insertions form a 
straight basal line. This allows species belonging to Bradysia to be easily determined. No fossil species have been previously detected in European amber. The following described species from Dominican amber are of ancestral feature with uniformly shaped hypopygium and without definitive connections to Central American species.

\section{Bradysia antiqua MoHRIG \& RösCHMANN n. sp. $\dagger$}

(Fig. $12 \mathrm{a}-\mathrm{e})$

\section{Description:}

$\sigma^{7}$. Head. Globular, eyes sparse and short setose, eye bridge complete, 3 facets wide. Antennae sixteen-segmented, with rounded pedicel and a shorter scape; flagellar segments fairly long and strong, with distinct necks; 4 . flagellomere about 2.4 times longer than wide, basal part bristle-like and as long as wide setose. Palpi three-segmented, basal segment with 2 bristles, 3rd. segment narrow and somewhat longer than the second segment; labelli large. Prefrons fairly dense setose, clypeus with 2-3 hairs.

\section{Thorax:}

Mesonotum with long central hairs; lateral and prescutellar hairs stronger; scutellum with 4 strong marginal bristles and few short hairs on the surface; posterior pronotum bare; antepronotum and prethoracal episternite with 3-4 short hairs; other pleural sclerites bare. Wings hyaline, with short and fine microtrichia, venation the same as in modern species; $\mathrm{R} 1=2 / 3 \mathrm{R}$; $\mathrm{R} 5$ only with dorsal macrotrichia; $\mathrm{C}=2 / 3 \mathrm{w} ; \mathrm{y}=\mathrm{x}$, with $1-2$ macrotrichia; posterior wing veins distinct (with exception of M-stem), without macrotrichia; fork of M narrow, shorter than M-stem; Cu1-stem fairly long, but shorter than $\mathrm{x}$. Halteres short club-shaped and sparse setose. Coxae and legs normally, not elongated or shortened; fore tibia with few short spine-like bristles within the short ground hair and with one strong apical spur, at the inner apex with a broad comb of bristle-like hairs; spurs of mid and hind tibia equal and long, much longer than the diameter of the apex; the hind tibiae with a posterior row of spines and a distinct apical spine-wreath. Claws untoothed, slightly curved.

\section{Abdomen:}

Tergal and sternal sclerites fairly dense and long setose. Hypopygium with a v-shaped ventral base without any differentiation; gonocoxites long, the inner ventral border sparse setose and the ventro-apical megaseta well developed; gonostyles prolonged, narrow and slightly curved, with a strong and broad apical tooth and a subapical group of 4 hyaline spines; above the tooth two spines and dense hair; tegmen apically rounded; aedoeagus fairly strong. Body length: $2.2 \mathrm{~mm}$.

\section{Material:}

Amber from Santiago Province as locus typicus, Dominican Republic.

Holotype: $1 \sigma^{\top}$, Reg.-Nr. D.-A. Sci. 12 (coll. Poinar). Specimen in best condition, side view, hypopygium in ventral position.

Paratypes: $1 \sigma^{\star}$, Reg.-Nr. D.-A. Sci. 13 coll. Poinar, side view, hypopygium in ventral position; $1 \sigma^{\star}$, Reg.-Nr. D.-A. Sci. 14 coll. Poinar, side view, in best condition, hypo- 
pygium well visible; 1 đa $^{\star}$, Reg.-Nr. 15 coll. PoInar, side view, hypopygium well visible, wings only by reorientation of the slide; 10 , coll. Mohrig (from coll. Poinar), side view, in good condition; all same locality.

\title{
Remarks:
}

The species is a representative of the genus Bradysia. The broad comb of bristles at the tip of fore tibiae and other characteristics as strong flagellomeres, short hair on eyes, wing venation, long and fairly strong tibial spurs and 4 strong bristles at the margin of scutellum are all typical. The species shows no connection with the known Holarctic speciesgroups.

\section{Bradysia exoleta MoHrig \& Röschmann n. sp. $\dagger$}

(Fig. 13 a-d)

\section{Description:}

$\sigma^{\star}$. Head. Globular, eyes sparse and fairly short setose, eye bridge complete, 3 facets wide, at the sides narrower. Antennae sixteen-segmented, with rounded pedicel and a shorter scape; flagellar segments fairly short; 4. flagellomere about 2 times longer than wide; basal part with somewhat bristle-like and erect hair as long as the diameter. Palpi short, three-segmented, basal segment with 1 bristle. Prefrons with some short hairs.

\section{Thorax:}

Mesonotum brown setose, with fairly long central hairs; lateral and prescutellar hairs somewhat longer; scutellum with 4 longer marginal bristles and few short hairs; posterior pronotum bare. Wings hyaline, with short and fine microtrichia, venation the same as in modern species; R1 very short, = 1/3 R; R5 only with dorsal macrotrichia; $\mathrm{C}$ short, = 1/2 $\mathrm{w} ; \mathrm{y}=\mathrm{x}$, without macrotrichia; posterior wing veins strong, without macrotrichia; Mfork broad and shorter than the M-stem; Cu1-stem = 1/2 x. Halteres short club-shaped and sparse setose. Coxae and legs normally, not elongated; fore tibia with one apical spur, at the inner apex with a comb of bristles; spurs of mid and hind tibia equal, thin and somewhat longer than the diameter of the apex; the hind tibiae with a posterior row of spines and a distinct apical spine-wreath. Claws untoothed, slightly curved.

\begin{abstract}
Abdomen:
Tergal and sternal sclerites fairly short setose. Hypopygium with a v-shaped ventral base without any differentiation; gonocoxites long, with long hairs at the inner ventral border in the upper half; the ventro-apical megaeta well developed; gonostyles elongate, narrow, the inner side somewhat bulbously, with a thin and curved apical tooth and 3 subapical spines, the lower two shorter; tegmen as high as broad, apically rounded; aedoeagus not well visible. Body length: 1,8 mm.
\end{abstract}

\section{Material:}

Amber from Santiago Province as locus typicus, Dominican Republic.

Holotype: $1 \sigma^{*}$, AMNH, no. DR-10-833, locality unknown; ventral view, hypopygium in ventral position, very well visible, legs also well visible, wings damaged. 
Paratypes: $1 \sigma^{\star}$, same piece of amber; $1 \sigma^{\star}, \mathrm{BMNH}$, Pal. PI II 180, purchased McCallum, Marcus 1994; ventral view, hypopygium very well visible; $1 \sigma^{\star}$, Santiago area, purchased H. Bradzinsky 1987 (in coll. Mohrig from AMNH no. 11690); 3 o o $\sigma^{\star}$, Reg.-Nr. Sci. 22, 22 a, 22 b (coll. Poinar), side view, in good conditions; $1 \sigma^{\star}$, Dominican amber, coll. Mohrig (from coll. Poinar).

\section{Remarks:}

This species belongs to the genus Bradysia through a comb-like row of bristles at the tip of the fore tibiae, bare posterior pronotum, and the shape and hair of hypopygium. It is characterized through the very short R1 and the short $\mathrm{C}$. The species has no connection with the known Holarctic species-groups. Small Bradysia species with short and broad wings and a very short $\mathrm{R}$ are known from undetermined material from Honduras and Costa Rica.

\section{Bradysia dimidiata MoHrig \& Röschmann n. sp. $\dagger$}

(Fig. 14 a-e)

\section{Description:}

$0^{\star}$. Head. Globular, eyes sparse and short setose, eye bridge complete, 4 facets wide. Antennae sixteen-segmented, with rounded pedicel and a shorter scape; flagellar segments short and strong, with distinct necks; 4. flagellomere about 1.5 times longer than wide, basal part bristle-like, fairly dense and as long as wide setose. Palpi three-segmented, basal segment fairly long, with 2-3 bristles, 3rd segment narrow and somewhat longer than the second segment.. Prefrons with few hairs.

\section{Thorax:}

Mesonotum with fairly long and dark central hairs; lateral and prescutellar hairs stronger; scutellum with 2 strong marginal bristles and few short hairs; posterior pronotum bare; antepronotum and prethoracal episternite with 3-4 shorter hairs; other pleural sclerites bare. Wings hyaline, with short and fine microtrichia, venation the same as in modern species; R1 = 2/3 R; R5 only with dorsal macrotrichia; $C=2 / 3 \mathrm{w} ; \mathrm{y}=\mathrm{x}$, without macrotrichia; posterior wing veins distinct, without macrotrichia; fork of $M$ narrow, shorter than M-stem; Cu1-stem short, = 1/2 x. Halteres dark, short club-shaped and sparse setose. Coxae and legs normally, not elongated or shortened; fore tibia with few short spine-like bristles within the short ground hair and with one fairly thin apical spur, the arrangement of bristles at the inner apex not well to seen, perhaps with a comb of bristle-like hairs; spurs of mid and hind tibia equal, long and fairly thin, longer than the diameter of the apex; the hind tibiae with a posterior row of spines and a distinct apical spine-wreath. Claws untoothed, slightly curved.

\section{Abdomen:}

Tergal and sternal sclerites fairly long setose. Hypopygium with a v-shaped ventral base without any differentiation; gonocoxites long, the ventro-apical megaseta well developed; gonostyles fairly short, narrowed to the tip and slightly curved, with a curved apical tooth; tegmen trapezoid; aedoeagus not visible. Body length: $1.5 \mathrm{~mm}$. 
Material:

Amber from Santiago Province as locus typicus, Dominican Republic.

Holotype: 1 ๙ $^{\star}$, BMNH, Pal. PI II 181, London; purchased McCallum, Marcus 1994; specimen in good condition, side view, hypopygium in dorsal position.

\section{Remarks:}

The species is similar to modern Holarctic Bradysia species, although the comb of bristles at the tip of fore tibiae is not visible. Other characteristics such as wing venation, shape of flagellomeres, hair on mesonotum, three-segmented palpi with few bristles on the basal segment and the legs with long tibial spurs point to this genus. The position within the genus Bradysia is not sure.

\section{Genus Corynoptera WinnerTz, 1867}

(Monogr. Sciarinen: 177)

Type species: Corynoptera perpusilla Winnertz, 1867 - Monogr. Sciarinen: 177)

The genus Corynoptera, much like Bradysia, contains one of the richest assortments of species among all recent sciarid genera. In contrast to Bradysia, it is distributed mainly within the Palearctic region. Relatively few species are known from the Nearctic region, four species from the Dominican Republic (MoHrig et al. 2004). In the whole southern hemisphere, there are only a few species which with any degree of certainty can be classified as belonging to Corynoptera (with exception of the fauna of NewZealand; the causes are discussed by Mohrig \& JaschHof 1999). From the European amber (Baltic and Saxonian amber), 13 species are described (MOHRIg \& RöschmanN 1994; Röschmann \& Mohrig 1995a, b), so that Corynoptera, along with Trichosia, Leptosciarella and Epidapus, is one of the typical faunistic elements of the tertian amber fauna.

The feature of the recent species of Corynoptera is very heterogeneous and shows a rich variety of morphological differentiations, especially in the shape and the arrangement of teeth and spines on the gonostyles and the shape of bristle patch at the tip of the inner side of fore tibiae. But all of the quite different species share two well developed apomorphic characteristics - only one bristle on the basal segment of the three-segmented palpi and two marginal bristles on the scutellum. These two characteristics, in connection with long mesonotal hair, bare posterior pronotum, lack of macrotrichia on the posterior wing veins, thin and fairly long antennal flagellomeres, thin and long legs with long spurs on mid and hint tibiae and a strong posterior row of spine-like bristles on the hind tibia, give a very good base for the phylogenetic relationship of most of the recent species. The following three described species are uniform in the shape and arrangement of tooth and spines on gonostyles and represent a more ancient type like the Palearctic species of the Corynoptera subtilis-group. 


\section{Corynoptera pristina Röschmann \& MOHRIG n. sp. $\dagger$}

(Fig. $15 \mathrm{a}-\mathrm{f}$ )

\section{Description:}

$0^{\star}$. Head. Globular, eyes sparse and short setose, eye bridge complete, 3 facets wide. Antennae sixteen-segmented, with rounded pedicel and a shorter scape; scape with a long and few shorter hairs; flagellar segments fairly long and strong, with distinct necks; 4. flagellomere about 2.5 times longer than wide, basal part bristle-like, somewhat fit tightly and shorter than wide setose. Palpi short, three-segmented, basal segment with fairly long sensilla and 1 bristle, 3rd. segment short and as long as the basal segment. Prefrons with some fairly long hairs, clypeus bare.

\section{Thorax:}

Mesonotum with fairly long central hairs; lateral and prescutellar hairs strong; scutellum with 2 strong marginal bristles and few short hairs; posterior pronotum bare; antepronotum and prethoracal episternite with 3-4 short hairs; other pleural sclerites bare. Wings hyaline, fairly narrow, with short and fine microtrichia, venation the same as in modern species; R1 = 2/3 R; R5 only with dorsal macrotrichia; $\mathrm{C}=2 / 3 \mathrm{w} ; \mathrm{y}=\mathrm{x}$, without macrotrichia; posterior wing veins distinct (with exception of $\mathrm{M}$-stem), without macrotrichia; Cu1-stem fairly short, shorter $1 / 2 \mathrm{x}$. Halteres fairly long club-shaped and sparse setose. Coxae and legs normally, not prolonged or shortened, graceful ; fore tibia with one apical spur, at the inner apex with an irregular comb-like patch of bristles; spurs of mid and hind tibia equal and long, much longer than the diameter of the apex; the hind tibiae with a strong posterior row of spines and a distinct apical spine-wreath. Claws untoothed, fairly long and slightly curved.

\section{Abdomen:}

Tergal and sternal sclerites fairly long setose. Hypopygium with a v-shaped ventral base without any differentiation; gonocoxites long, the ventro-apical megaseta well developed; gonostyles elongate, narrow and slightly curved, with a strong apical tooth and subapically with two thin hyaline spines; tegmen and aedoeagus not visible. Body length: $1.8 \mathrm{~mm}$.

\section{Material:}

Amber from Santiago Province as locus typicus, Dominican Republic.

Holotype: $1 \sigma^{\star}$, Reg.-Nr. D.-A. Sci. 20 (coll. Poinar), Oregon, USA; specimen in best condition, side view, hypopygium in ventral position.

\section{Remarks:}

The species is a typical representative of the modern genus Corynoptera, characterized by three-segmented palpi with only one bristle on the basal segment, bare posterior pronotum, fairly long mesonotal hair with strong lateral and prescutellar bristles and only two strong bristles on the posterior margin of scutellum. The species is very similar to the recent Palearctic species C. perpusilla Winnertz 1867 and C. sphenoptera Tuomikoski 1960 , which, with simple shaped gonostyles, a single apical tooth and few subapical spines, represents a central basis group of the genus. The species is also well characterized by the size and arrangement of subapical spines and the shape and hair of antennae. 


\section{Corynoptera prisca MoHrig \& Röschmann n. sp. $\dagger$}

(Fig. 16 a-c)

\section{Description:}

${ }^{7}$. Head. Globular, eyes sparse and short setose, eye bridge complete, 4 facets wide. Antennae sixteen-segmented, with rounded pedicel and a shorter scape; flagellar segments long, with fairly long necks; 4 . flagellomere about 3 times longer than wide, basal part stand up and somewhat longer than wide setose. Palpi three-segmented, basal segment narrow, with 1 bristles, third segment narrow and somewhat shorter than the basal segment; labelli large. Prefrons fairly dense setose, with some longer curved hairs.

\section{Thorax:}

Mesonotum pale setose, with fairly short central hairs; lateral and prescutellar hairs stronger; scutellum with 2 strong marginal bristles and few short hairs; posterior pronotum bare. Wings hyaline, with short and fine microtrichia, venation the same as in modern species; R1 fairly short, somewhat longer 1/2 R; R5 only with dorsal macrotrichia; C longer $1 / 2 \mathrm{w}$; $\mathrm{y}$ somewhat shorter $\mathrm{x}$, without macrotrichia; posterior wing veins distinct, without macrotrichia; Cu1-stem distinct, $=1 / 2 \mathrm{x}$. Halteres club-shaped and sparse setose. Coxae and legs normally, not elongated or shortened; fore tibia with few short spine-like bristles within the short ground hair and with one long apical spur, at the inner apex with a comb-like patch of bristles; spurs of mid and hind tibia equal and long, much longer than the diameter of the apex; the hind tibiae with a posterior row of spines and a distinct apical spine-wreath. Claws untoothed, fairly long and slightly curved.

\section{Abdomen:}

Tergal and sternal sclerites sparse, pale and fine setose. Hypopygium with a v-shaped ventral base without any differentiation; gonocoxites long, the ventro-apical megaseta well developed; gonostyles elongate, narrow and slightly curved, with a long, slightly curved apical tooth and three ling equal subapical spines, one beside the base of the tooth, two as a pair under the tooth; tegmen and aedoeagus not visible. Body length: $2 \mathrm{~mm}$.

\section{Material:}

Amber from Santiago Province as locus typicus, Dominican Republic.

Holotype: 1 ○َ, BMNH Pal. PI II 652-(2), London, purchased R. RonTAler, Febr. 1995. Specimen in good condition, side view, hypopygium in ventral position, somewhat deformed by drying up.

Paratypes: 1 o , BMNH Pal. PI II 182, London, purchased McCallum, Marcus 1994. Ventral view, hypopygium in best condition, wings, legs and head good visible by perepreparation of slide; $1 \sigma^{\star}$, (coll. Mohrig, from BMNH, Pal. PI II 646, purchased R. Rontaler, Febr. 1995), ventral view, hypopygium well visible, wings damaged; $1 \sigma^{*}$, BMNH Pal. PI II 649, side view, hypopygium in ventral position; 1 đ ${ }^{\star}$, Reg. Nr. 19 (coll. Poinar), side view, in good condition, hypopygium well visible; all Dominican Amber, unknown locality; 1 o , AMNH, no. DR-6-164 11838 B, New York; specimen in good condition, side view, hypopygium in ventral position, antennae somewhat tried; $2 \sigma^{*} \sigma^{*}$, AMNH, no. DR-10-817, (two specimens in the same amber piece), specimens in good conditions, hypopygium in ventral position; localities unknown. 


\section{Remarks:}

The species belongs to Corynoptera by the only one bristle on the basal segment of palpi, two strong bristles on the margin of scutellum, long flagellomeres and long tibial spurs. It is similar to $C$. pristina and belongs therefore to species near the recent subtilis-group., distributed within the Palearctic regon. The species is characterized by the long and slightly curved apical tooth of gonostyles accompanied by three equally long subapical spines.

\section{Corynoptera iocosa MoHRIg \& Röschmann n. sp. $\dagger$}

(Fig. $17 \mathrm{a}-\mathrm{c}$ )

\section{Description:}

$0^{\star}$. Head. Globular, eyes sparse and short setose, eye bridge complete, 3 facets wide, at the sides narrower. Antennae sixteen-segmented, with rounded pedicel and a shorter scape; flagellar segments fairly long and strong, with distinct necks; 4. flagellomere about 2.2 times longer than wide, basal part bristle-like, stand up and as long as wide setose. Palpi short, three-segmented, basal segment with one bristle, 3rd. segment short and as long as the basal segment. Prefrons with some hairs, clypeus bare.

\section{Thorax:}

Mesonotum pale setose; lateral and prescutellar hairs stronger; scutellum with 2 long marginal bristles and few short hairs; posterior pronotum bare; antepronotum and prethoracal episternite with few fine hairs; other pleural sclerites bare. Wings very hyaline, with short and fine microtrichia, venation the same as in modern species; R1 very short, = 1/3 R; R5 only with dorsal macrotrichia; $\mathrm{C}$ a little longer $1 / 2 \mathrm{w} ; \mathrm{y}=\mathrm{x}$, without macrotrichia; posterior wing veins very weak, without macrotrichia; Cu1-stem $=1 / 2 \mathrm{x}$. Halteres short club-shaped and sparse setose. Coxae and legs normally, not elongated or shortened; fore tibia with one apical spur, at the inner apex with an irregular comb-like patch of bristles; spurs of mid and hind tibia equal, thin and somewhat longer than the diameter of the apex; the hind tibiae with a posterior row of spines and a distinct apical spine-wreath. Claws untoothed, slightly curved.

\section{Abdomen:}

Tergal and sternal sclerites short and sparse setose. Hypopygium with a v-shaped ventral base without any differentiation; gonocoxites long, the ventro-apical megaseta well developed; gonostyles elongate, narrow, the inner side somewhat bulbously, with a strong more subapically positioned tooth and two thin hyaline subapical spines and few long bristles, a shorter bristle-like spine above the mid of the inner side; tegmen and aedoeagus not visible. Body length: $1.2 \mathrm{~mm}$.

\section{Material:}

Amber from Santiago Province as locus typicus, Dominican Republic.

Holotype: 1 đ`, AMNH 11838 B, New York, La Vega, La Vega Prov., purchaded J. BrodZINSKY 1987. Specimen in good condition, side view, hypopygium in ventral position, wings deformed. 
Paratypes: $20^{\star} \sigma^{\star}$, BMNH, Pal. PI II 184, London, purchased McCallum, Marcus 1994 (in same amber piece), side view, non transparent, hypopygium well visible; $1 \sigma^{\star}$, coll. Mohrig (from BMNH Pal. PI II 655-(1).

\section{Remarks:}

The position of this species within Corynoptera is not so clear. The pale and fairly short mesonotal hair, the not strong posterior row of spines on the hind tibiae and the subapical position of the strong tooth on gonostyles in connection with a bristle-like spine at the inner side are reminiscent of species of the recent $C$. blanda-group, distributed within the Palearctic region.

\section{Genus Epidapus Haliday, 1851}

(in WALKer, 1851: Ins. Brit. Dipt., 1: 7)

Type species: Chionea venatica Haliday, 1856 (= Tipula atomaria De Geer, 1778).

The feature of the genus was defined by the well known Palearctic species E. atomarius (DEgeER), E. gracilis (WALKer) and E. microthorax (Börner). Males are usually, easily recognised by the long flagellomeres, long halteres, long legs, narrow base of wings and one- or two-segmented palpi. Male genitalia within the typical species-group of Epidapus s.str. show fairly short gonostyles with a moderately strong tooth at the apex and some hyaline spine-like bristles (some other species lost the apical tooth). Females differ from the male through shorter flagellomeres and the absence or strong reduction of wings and halteres in many species.

The species of Epidapus has been seen up to now as a young evolutionary group of Sciaridae (FREY 1942) by their tendency toward reduction of constitutive morphologic structures in connection with the unusual specialisation of long halteres. New data presented from investigations of the sciarid fauna of Baltic and Saxonian amber demonstrate that typical Epidapus species were living within the Oligocene at least $35 \mathrm{My}$ (MoHrig \& Röschmann 1994, Röschmann \& MOHRIg 1994).

The genus is distributed world-wide (Mohrig \& Jaschhof 1999, Mohrig 2002). The detected species of the Dominican amber are differentiated from those of the Baltic and Saxonian amber by lack of morphologic specialisations as long halteres, prolonged legs, long flagellomere, narrow wing base or broad M-fork. Broader wings, shorter legs and halteres are more common in Epidapus species of the southern hemisphere.

\section{Epidapus microspinus Mohrig \& Röschmann n. sp. $\dagger$}

(Fig. 18 a-f)

\section{Description:}

$0^{\star}$. Head. Globular, eyes sparse and short setose, eye bridge complete, 4 facets wide. Antennae sixteen-segmented, with rounded pedicel and a shorter scape; flagellar segments fairly short and strong, with fairly short necks; 4. flagellomere about 2 times longer than wide, basal part bristle-like, up standing and as long as wide setose. Palpi one-segmented. 


\section{Thorax:}

Mesonotum with fairly short central hairs; lateral and prescutellar hairs strong; scutellum with 2 long and 2 shorter marginal bristles and few short hairs; posterior pronotum bare; antepronotum and prethoracal episternite sparse an short setose; other pleural sclerites bare; katepisternite directed at the back. Wings hyaline, broad, with short and fine microtrichia; R1 = 2/3 R; R5 short, only with dorsal macrotrichia; C longer $1 / 2 \mathrm{w} ; \mathrm{y}=\mathrm{x}$, with macrotrichia; posterior wing veins weak, without macrotrichia; $\mathrm{Cu} 1$-stem shorter $1 / 2 \mathrm{x}$. Halteres fairly long, club-shaped and sparse setose. Coxae and legs slender, but not elongated; fore tibia without bristle-like spines within the ground hair, with one short and thin apical spur, at the inner apex with few longer hairs, but without a distinct patch of bristles; spurs of mid and hind tibia equal, short and thin, but not shorter than the diameter of the apex; the hind tibiae without a posterior row of spines, only somewhat longer setose and without a distinct apical spine-wreath. Claws untoothed, fairly long.

\section{Abdomen:}

Tergal and sternal sclerites fairly sparse and short setose. Hypopygium with a v-shaped ventral base without any differentiation; gonocoxites as long as the gonostyles, the ventroapical megaseta developed; gonostyles elongate, narrowed and slightly curved at the tip, with a very short apical tooth (without any hyaline subapically bristle-like spines) in an equal long hair; tegmen broader than high; aedoeagus not visible. Body length: $1.5 \mathrm{~mm}$.

\section{Material:}

Amber from Santiago Province as locus typicus, Dominican Republic.

Holotype: $1 \sigma^{\star}$, Reg.-Nr. D.-A. Sci. 25 (coll. Poinar), Oregon, USA; specimen in best condition, side view, hypopygium in ventral position.

Paratype: 1 đَ, AMNH, New York, no. 11663 C, Santiago; ventral view, wings damaged, hypopygium well visible, body not transparent.

\section{Remarks:}

This species is a representative of the recent genus Epidapus, characterized by one-segmented palpi and short and fine tibial spurs. It belongs to Epidapus s. str. by the apical tooth. The species is characterized furthermore by macrotrichia on y, which is not common within the genus Epidapus.

\section{Epidapus macrospinatus Mohrig \& Röschmann n. sp. $\dagger$}

(Fig. 19 a-d)

\section{Description:}

$\sigma^{\star}$. Head. Globular; antennae sixteen-segmented, with rounded pedicel and a shorter scape; fairly long flagellar segments, fairly long necks; 4. flagellomere about 2.2 times longer than wide, basal part bristle-like, up standing and as long as wide setose. Palpi one-segmented.

\section{Thorax:}

Mesonotum with long central hairs; lateral and prescutellar hairs long. Wings hyaline, fairly broad, with short and fine microtrichia; $\mathrm{R} 1=2 / 3 \mathrm{R} ; \mathrm{y}=\mathrm{x}$, without macrotrichia; posterior 
wing veins weak, without macrotrichia; Cu1-stem fairly long, =1/2 x. Halteres fairly long, club-shaped and sparse setose. Coxae and legs slender, but not elongated; fore tibia without bristle-like spines within the ground hair, with one short and thin apical spur, at the inner apex with few longer hairs, but without a distinct patch of bristles; spurs of mid tibia equal, fairly short and thin, but not shorter than the diameter of the apex. Claws untoothed.

\section{Abdomen:}

Tergal and sternal sclerites fairly long setose. Hypopygium with a v-shaped ventral base without any differentiation; gonocoxites as long as the gonostyles, the ventro-apical megaseta developed; gonostyles prolonged, narrow, with a strong apical tooth (without any hyaline subapically bristle-like spines) in shorter apical hair; tegmen and aedoeagus not visible. Body length: $1.2 \mathrm{~mm}$.

\section{Material:}

Amber from Santiago Province as locus typicus, Dominican Republic.

Holotype: $1 \sigma^{\star}$, Reg.-Nr. D.-A. Sci. 28 (coll. Poinar), Oregon, USA; specimen in sloping dorsal side view, hypopygium in ventral position, well visible, wings damaged.

Paratype: $1 \sigma^{\star}$, locus typicus, coll. Mohrig (from coll. Poinar).

\section{Remarks:}

The species is a representative of the recent genus Epidapus, characterized by one-segmented palpi and short and fine tibial spurs. It belongs to Epidapus s. str. by the strong apical tooth. The shape of gonostyles is somewhat deformed by drying.

\section{Epidapus adstrictosetus MoHRIg \& RöschmanN n. sp. $\dagger$}

(Fig. 20 a-d)

\section{Description:}

$0^{\star}$. Head. Globular, eyes sparse and short setose, eye bridge complete, 3-4 facets wide. Antennae sixteen-segmented, with rounded pedicel and a shorter scape; flagellar segments with fairly long necks and strong fit tightly hair; 4. flagellomere about twice as long as wide, basal part as long as wide setose. Palpi one-segmented.

\section{Thorax:}

Mesonotum with fairly long central hairs; lateral and prescutellar hairs longer; scutellum with 2 long and 2 short marginal bristles and few short hairs; posterior pronotum bare; katepisternite directed at the back. Wings hyaline, broad, with short and fine microtrichia; R1 = 2/3 R; R5 short, only with dorsal macrotrichia; C long = 2/3 w; $y=x$, without macrotrichia; posterior wing veins weak, without macrotrichia; Cu1-stem shorter 1/2 $\mathrm{x}$. Halteres fairly long, club-shaped and sparse setose. Coxae and legs slender, but not elongated; fore tibia without bristle-like spines within the fairly long ground hair, with one short and thin apical spur, at the inner apex with few longer hairs, but without a distinct patch of bristles; spurs of mid and hind tibia equal, short and thin, as long or somewhat shorter than the diameter of the apex; the hind tibiae with a posterior row of spines, but without a distinct apical spine-wreath. Claws untoothed, fairly long and slightly curved. 


\section{Abdomen:}

Tergal and sternal sclerites fairly sparse and short setose. Hypopygium with a v-shaped ventral base without any differentiation; gonocoxites as long as the gonostyles, the ventro-apical megaseta developed; gonostyles elongate and rounded at the tip, long setose at the outer sides, with 5-6 long spine-like bristles apically and 2-3 long hairs in the mid of the inner side; tegmen and aedoeagus not visible. Body length: $1.5 \mathrm{~mm}$.

\section{Material:}

Amber from Santiago Province as locus typicus, Dominican Republic.

Holotype: $1 \sigma^{\star}$, Reg.-Nr. D.-A. Sci. 26 (coll. Poinar), Oregon, USA; specimen in good condition, side view, hypopygium in ventral position, body not transparent.

Paratype: $1 \sigma^{\star}$, Reg.-Nr. D.-A. Sci. 27 (coll. PoinAr), Oregon, USA; side view, wings damaged, hypopygium not visible (in same piece of amber as E. longisetus).

\section{Remarks:}

This species is characterized by one-segmented palpi, short and fine tibial spurs, long C (M1 is joining far behind the tip of wings) and especially by the long hair of antennal flagellomeres. It is similar to recent Palearctic species of the subgenus Pseudoaptanogyna, especially of the E. ignava-group by the lack of an apical tooth and stronger spines at the tip of gonostyles.

\section{Epidapus longisetus Mohrig \& Röschmann n. sp. $\dagger$}

(Fig. 21 a-e)

\section{Description:}

$0^{\star}$. Head. Globular, eyes sparse and short setose, eye bridge complete, 2-3 facets wide. Antennae sixteen-segmented, with rounded pedicel and a shorter scape; flagellar segments long, with fairly long necks; 4. flagellomere about 2,5 times longer than wide, basal part bristle-like, up standing and longer wide setose. Palpi short two-segmented.

\section{Thorax:}

Mesonotum with fairly long central hairs; lateral and prescutellar hairs longer; scutellum with 2 long and 2 shorter marginal bristles and few short hairs; posterior pronotum bare; katepisternite directed caudally. Wings somewhat brownish, fairly broad, with anal angle clearly narrowed, with short and fine microtrichia; R1 = 2/3 R; R5 only with dorsal macrotrichia; $\mathrm{C}$ longer $1 / 2 \mathrm{w}$; $\mathrm{y}=\mathrm{x}$, without macrotrichia; posterior wing veins weak, without macrotrichia; M-fork fairly broad and directed at the back; Cu1-stem shorter 1/2 x. Halteres fairly long, club-shaped and sparse setose. Coxae and legs slender, clearly elongated, especially $\mathrm{p} 1$; fore tibia without bristle-like spines within the fairly long ground hair, with one moderately long and thin apical spur, at the inner apex with a small patch of row-like arranged longer bristles; spurs of mid and hind tibia equal, long and thin, longer than the diameter of the apex; the hind tibiae with a fairly strong posterior row of spines, but without a distinct apical spine-wreath. Claws untoothed, fairly long. 


\section{Abdomen:}

Tergal and sternal sclerites fairly sparse, but long setose. Hypopygium with a v-shaped ventral base without any differentiation; gonocoxites longer than the gonostyles, the ventro-apical megaseta developed; gonostyles short, basally broad and strongly narrowed to the tip, with a long and thin apical tooth and 2 or 3 hyaline subapically bristle-like spines; tegmen large and broad; aedoeagus not visible. Body length: $1.6 \mathrm{~mm}$.

\section{Material:}

Amber from Santiago Province as locus typicus, Dominican Republic.

Holotype: $1 \sigma^{\star}$, Reg.-Nr. D.-A. Sci. 27 (coll. Poinar), Oregon, USA (same amber piece as the paratype of $E$. adstrictosetus); specimen in good condition, side view, hypopygium in ventral position, somewhat sloping.

Paratype: $1 \sigma^{\star}$, Reg.-no. D.-A. Sci. 20 (coll. PoInAR), Oregon, USA (same amber piece as $C$. pristina); side view, hypopygium sloping, without antennae.

\section{Remarks:}

This species represents the feature of species of Epidapus s. str. around the recent $E$. $m i$ crothorax (BöRNER 1903). It is characterized through the short gonostyles (strong narrowed to the tip and with a slender apical tooth and some subapical bristle-like spines), long antennal segments with fairly long necks and a long bristle-like hair, and slender and clearly prolonged legs.

\section{Discussion}

About 100 pieces of Dominican amber were studied. Only males are useful for exact determination in the level of genera and species according to the current taxonomic knowledge of the Sciaridae. This investigation described of 20 new fossil species and one new genus with three fossil and one recent species. None of the species identified in the Domincian amber were identical with those from the Baltic amber and the paraautochtone Saxonian (Bitterfeld) amber samples. However, several genera, such as Trichosia, Leptosciarella, Cratyna, Corynoptera and Epidapus, were common to all three.

Unique to the Dominican amber are the genera Chaetosciara, Archicratyna, Bradysiopsis and Bradysia. All species from the Dominican amber belong to recent genera or subgenera, whereas many species from the Baltic and Saxonian amber belong to extinct genera or subgenera. Furthermore, the species from the Dominican amber have more modern features than those from the European amber and could be sister taxons of living species.

Thus, there is an apparent discrepancy between the faunistic elements of the Saxonian amber and the Dominican amber, both of which have approximately the same calculated age of 20-24 My. The Saxonian amber fauna contains many of the identical species as the much older Baltic amber and the appearance of the typical characteristics is far different from recent representatives of respective genera. These observations offer evidence of a greater than suspected temporal proximity in the resin production of the fennoscandian amber forests and the amber forests located south of the tertiary Baltic Sea (Saxonia). If the species of Dominican amber are more recently derived than the more primitive species of Saxonian amber with respect to living representatives of comparative genera, than 
we have a discrepancy between the biostratigraphically estimated age of Saxonian amber and its older sciarid fauna (RöschmanN 1997).

In general, the observations on amber sciarids agree with data from other families of flies and other insect groups (bees, ants) in that the fauna of Dominican amber is clearly more modern than that of Baltic amber (GRIMALDi 1987, 1991). This conclusion supports the opinion of a correctly estimated age of Dominican amber of about 20-23 My and favors the view that resin production in the minefields around Bitterfeld must have occurred earlier than previously estimated.

Of special interest is the fact that the differences between the sciarid fauna of Baltic/ Saxonian amber and the fauna of Dominican amber regarding represented genera and subgenera is far less distinct than the present differences between the recent fauna of the Palearctic region and Central America. In other words, the sciarid fauna of Dominican amber shows more similarities with the recent fauna of the Holarctic region than with the recent fauna of Central and South America. The sciarid genera identified in Baltic/ Saxonian amber are also recently distributed, mainly in the Palearctic region (Trichosia, Leptosciarella, Corynoptera). In contrast, the Dominican amber do not contain any species of genera endemic, or at least representative, of the recent fauna of Central or South America (Pseudosciara, Rhynchosciara, Odontosciara, Zygomma, Pseudolycoriella).

The known species of the subgenus Mouffettina are distributed Palearctic and reach the Nearctic region with only one species. Leptosciarella is also mainly Holarctic distributed and reaches the equatorial regions in the Old and New World with only a few species. Chaetosciara is eastern Palearctic and Orientalic distributed and with only a single species found in the Dominican Republic. Bradysiopsis is a genus with only three recent species known from Europe and Central Asia; Corynoptera is a species rich genus of the Palearctic region and enters the New World with only few species. Bradysia is species rich in all continents and splits off into many differentiated species groups. The exceptions to this general view are Cratyna tempestiva and the species of the new genus Archicratyna. The subgenus Cratyna s. str. is globally distributed and species with comparable features to Cratyna tempestiva are common both in Central and South America and in the Orientalic region.

Highly surprising is the discovery of the new genus Archicratyna with three fossil species and one recent species from Africa (Zimbabwe). This observation aggravated the problem of explaining the origin of the sciarid fauna in the Dominican amber. The oldest records of Sciaridae are undetermined specimens from the Cretacenous amber of approx. $120 \mathrm{My}$. The Bibiomorpha, the family group which includes the sciarids, is much older than these amber samples (Kovalev 1986) and suggests the opinion that the generic specification took place sometime before the break-up of the Pangea in the Late Triassic period. This explains the worldwide distribution of certain genera as well as the zoogeographic differences between the eastern and western hemispheres or the Old and New World. Also, in a compact land mass, such as Pangea, the distribution of distinct elements of given taxons is never homogenous and the separation by the break-up of continents leads to a random selection.

The last intercontinental bridge which existed during this lengthy geological process was between the northern part of South America and Africa in the Early Cretaceous, whereas the land bridge between South and Central America was at this time interrupted. 
These tectonic movements had an important effect on the development of the Caribbean sheet with the island chain of Greater Antilles. From the Mid Mesozoic up to the Early Tertiary, this chain was more closely connected to the current land mass locations of Yucatan, Florida and the Bahaman sheet than to South America.

The dominance of species in the Dominican amber fauna with definitive connections to the recent Holarctic sciarid fauna seems to reflect a prehistorical moment during the origin of the complicated insect fauna of the Greater Antilles. The proximity of this Caribbean island chain to North America through its geological history and the lengthy interruption of faunistic exchange with South America shows evidence of the great influence of the Holarctic sciarid fauna. Later, the northern taxons gradually died out, especially in times of environmental changes during glaciation periods. They were replaced by invading South American species after the restoration of the land bridge in the Tertiary and the commencement of faunistic exchange between the islands of the Greater Antilles and the island arch of Lesser Antilles, which had greater geological connections to the recent Venezuela. This is supported by the fact that the recent sciarid fauna of the Dominican Republic also contain more species with connections to the Holarctic fauna than to the fauna of Central and South America.

In summary, we can state that due to the comparatively recent commencement of resin production, these samples of amber-embedded sciarids are not very helpful in deciphering the phylogeny of this family. The results confirm the opinion that investigations on amber insects are much more important for reconstructing paleozoogeographic situations and explaining the establishment of the fauna in different zoogeographic regions today.

\section{Literature}

Brouwer, S. B. \& Brouwer, P. A. 1982: Geologia de la region amberifera oriental de la Republica Dominicana. - Proc. $9^{\text {th }}$ Caribbean Geological Conference, Santo Domingo: 303-332.

Frey, R. 1942: Entwurf einer neuen Klassifikation der Mückenfamilie Sciaridae (Lycoriidae). - Notul. Ent., Helsinfors [Helsinki] 22: 5-44.

Grimaldi, D. A. 1987: Amber Fossil Drosophilidae (Diptera), with Particular Reference to the Hispaniolan Taxa. - Am. Mus. Novitates 2880: 23 pp.

Grimaldi, D. A. 1991: Mycetobiine Woodgnats (Diptera: Anisopodidae) from the Oligo-Miocene Amber of the Dominican Republic, and Old World Affinities. - Am. Mus. Novitates 3014: 24 pp.

Kovalev, V. G. 1983: (A new family of the Diptera from the Triassic deposits of Australia and ist presumable descendants [Diptera, Crosaphidae fam. n., Mycetobioidea]). - Ontomol. Oboszr., Leningrad 62 (4): 800-804.

Menzel, F. \& Mohrig, W. 1997: 2.6. Family Sciaridae. - In: Papp, L. \& Darvas, B. [Hsg.]: Contributions to a Manual of Palearctic Diptera (with special reference to flies of economic importance). Volume 2: Nematocera and lower Brachycera. - Science Herald, 2: 51-69; Budapest.

Menzel, F. \& Mohrig, W. 1998: Beiträge zur Taxonomie und Faunistik der paläarktischen Trauermücken (Diptera, Sciaridae). Teil VI. - Neue Ergebnisse aus Typenuntersuchungen und die daraus resultierenden taxonomisch-nomenklatorischen Konsequenzen. - Studia dipterologica, 5 (2): 351-378; Halle/Saale.

Menzel, F. \& Mohrig, W. 1999: Revision der paläarktischen Trauermücken (Diptera: Sciaridae). - Studia dipterologica Supplement 6: 1-761; Ampyx-Verlag Halle/Saale.

Meunier, F. 1904: Monographie des Cecidomyidae, des Sciaridae, des Mycetophilidae et des -Chironomidae de l' ambre de la Baltique. - Ann. Soc. Scient. Brux., Louvain 28 (2): 12-275. 
Mohrig W. 1999: Die Trauermücken (Diptera: Sciaridae) von Papua-Neuguinea. Teil I - Gattung Sciara, Schwenckfeldina, Aerumnosa gen. nov., Cratyna, Phytosciara und Chaetosciara. - Studia dipterologica 6 (1): 153-203.

Mohrig W. 2002: Die Trauermücken (Diptera: Sciaridae) von Papua-Neuguinea. Teil II - Gattung Scythropochroa, Cratyna (Untergattung Pictosciara subgen. nov.), Pseudozygomma gen. nov., Epidapus mit Macrotarsus subgen. nov., Pnyxia, Corynoptera, Keilbachia, Scatopsciara und Pelliciplanta gen. nov. - Studia dipterologica [in press].

Mohrig W. \& Jaschrof, M. 1999: Sciarid Flies (Diptera, Sciaridae) of New Zealand. - Studia dipterologica Supplement, 7 (1999): 1-97; Ampyx-Verlag Halle/Saale.

Mohrig W. \& Röschmann, F. 1994: Revision der der Trauermücken-Typen von Loew und Meunier aus dem Baltischen Bernstein (Diptera, Sciaridae). - Dt. Ent. Z. (N. F.), Berlin 41 (1): 79-136.

Poinar, G. O. 1992: Life in amber. - Stanford, Stanford University Press, 1-321.

Röschmann, F. 1997: Ökofaunistischer Vergleich von Nematoceren-Faunen (Insecta; Diptera: Sciaridae und Ceratopogonidae) des Baltischen und Sächsischen Bernsteins (Tertiär, Oligozän-Miozän). - Paläont. Z., Stuttgart 71 (1-2): 79-87.

Röschmann, F. \& Mohrig, W. 1993: Beiträge zur Kenntnis fossiler Trauermücken (Diptera, Sciaridae) aus dem Sächsischen Bernstein. Teil I. Erster fossiler Nachweis der Gattung Epidapus Haliday. - Veröff. Naturhist. Mus. Schleusingen, Hildburghausen 7-8: 77-81.

Röschmann, F. \& Mohrig, W. 1994a: Einschlüsse fossiler Trauermücken (Diptera, Sciaridae) in Baltischem Bernstein aus Kollektionen des Deutschen Entomologischen Instituts Eberswalde. - Beiträge zur Entomologie, Berlin 44 (2): 403-408.

Röschmann, F. \& Mohrig, W. 1994b: Checklist of fossil sciarids from Baltic amber (Diptera, Sciaridae). - Studia dipterologica [Studia Dipt.], Halle/Saale 1 (1): 126-138.

Röschmann, F. \& Mohrig, W. 1995a: Die Trauermücken des Sächsischen Bernsteins aus dem Untermiozän von Bitterfeld/Deutschland (Diptera, Sciaridae). - Dt. Ent. Z. (N. F.), Berlin 42 (1): 17-54.

Röschmann, F. \& Mohrig, W. 1995b: Beiträge zur Kenntnis fossiler Trauermücken aus Sächsischem Bernstein. Teil II. Drei neue Sciariden aus Tertiär-Harzen des Bitterfelder Braunkohlenreviers (Insecta, Diptera, Sciaridae). - Paläont. Z., Stuttgart 69 (1-2): 153-166.

Röschmann, F. \& Mohrig, W. 1995c: Die Trauermücken des Baltischen und des Sächsischen Bernsteins (Diptera, Sciaridae). - Mitt. Dt. Ges. Allg. Angew. Ent., Giessen [Gießen] 10 (1-6): 637-640.

Schumann, H. \& Wendt, H. 1989: Zur Kenntnis der tierischen Inklusen des SächsischenBernsteins. - Dt. Ent. Z. (N. F.), Berlin 36: 33-44.

Steffan, W. A. 1969: Insects of Micronesia. Diptera: Sciaridae. - Insects of Micronesia, Honolulu, 12 (7): 669-732.

Steffan, W. A. 1989: 11. Family Sciaridae. - In: Evenhuis, N. L. [Hsg.]: Catalog of the Diptera of the Australasian and Oceanian Regions. - Bishop Mus. Sp. Publ., Honolulu 86: 146-151.

Tuомікоsкi, R. 1960: Zur Kenntnis der Sciariden (Diptera) Finnlands. - Ann. Zool. Soc. „Vanamo“, Helsinki 21 (4): 1-164.

\section{Author's address:}

Prof. Dr. sc. nat. Werner Mohrig

Puddemin 6

D-18574 Poseritz

Germany

e-mail:wmohrig@hotmail.com 


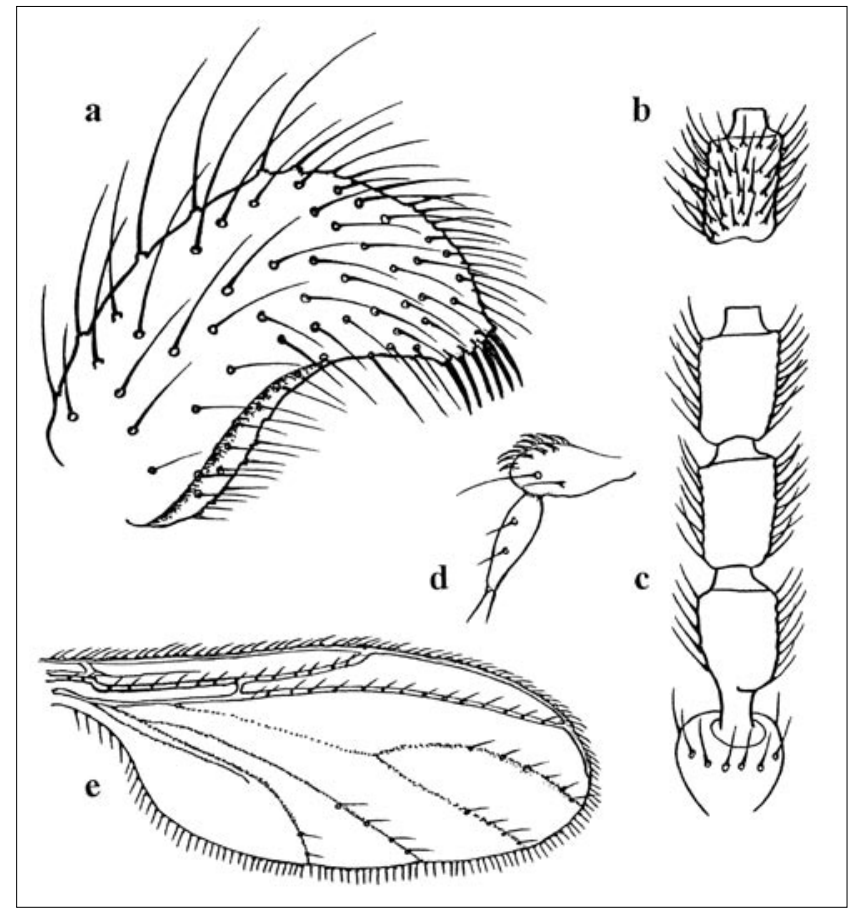

Fig. 1: Trichosia (Mouffetina) nova sp. n. †. a) gonostylus, x 400; b) flagellomere 4; c) basal part of antennae with pedicel and flagellomeres 1-3; d) palpus; x 200; e) wing, x 30 .

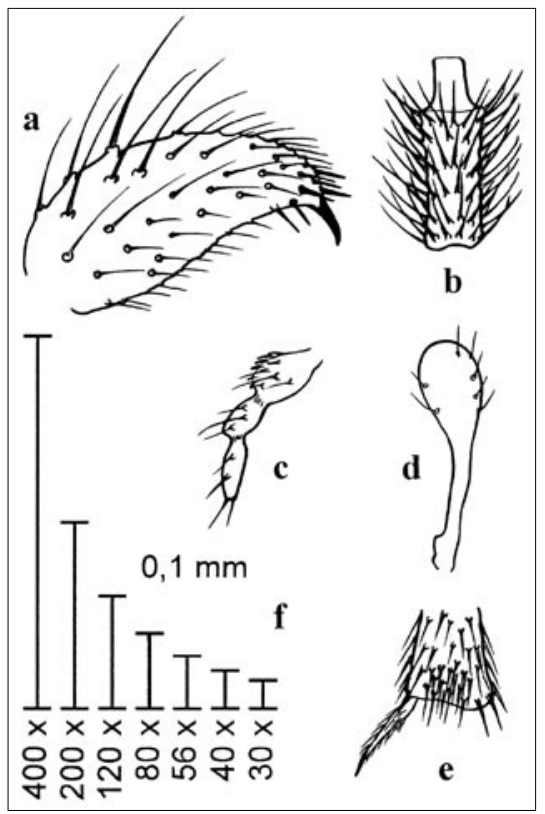

Fig. 2: Leptosciarella (Leptosciarella) manifesta sp. n. †. a) gonostylus $\mathrm{x} 400$; b) flagellomere 4; c) palpus; d) haltere; e) tip of fore tibia, $\mathrm{x} 200$; f) magnification in $\mathrm{mm}$. 


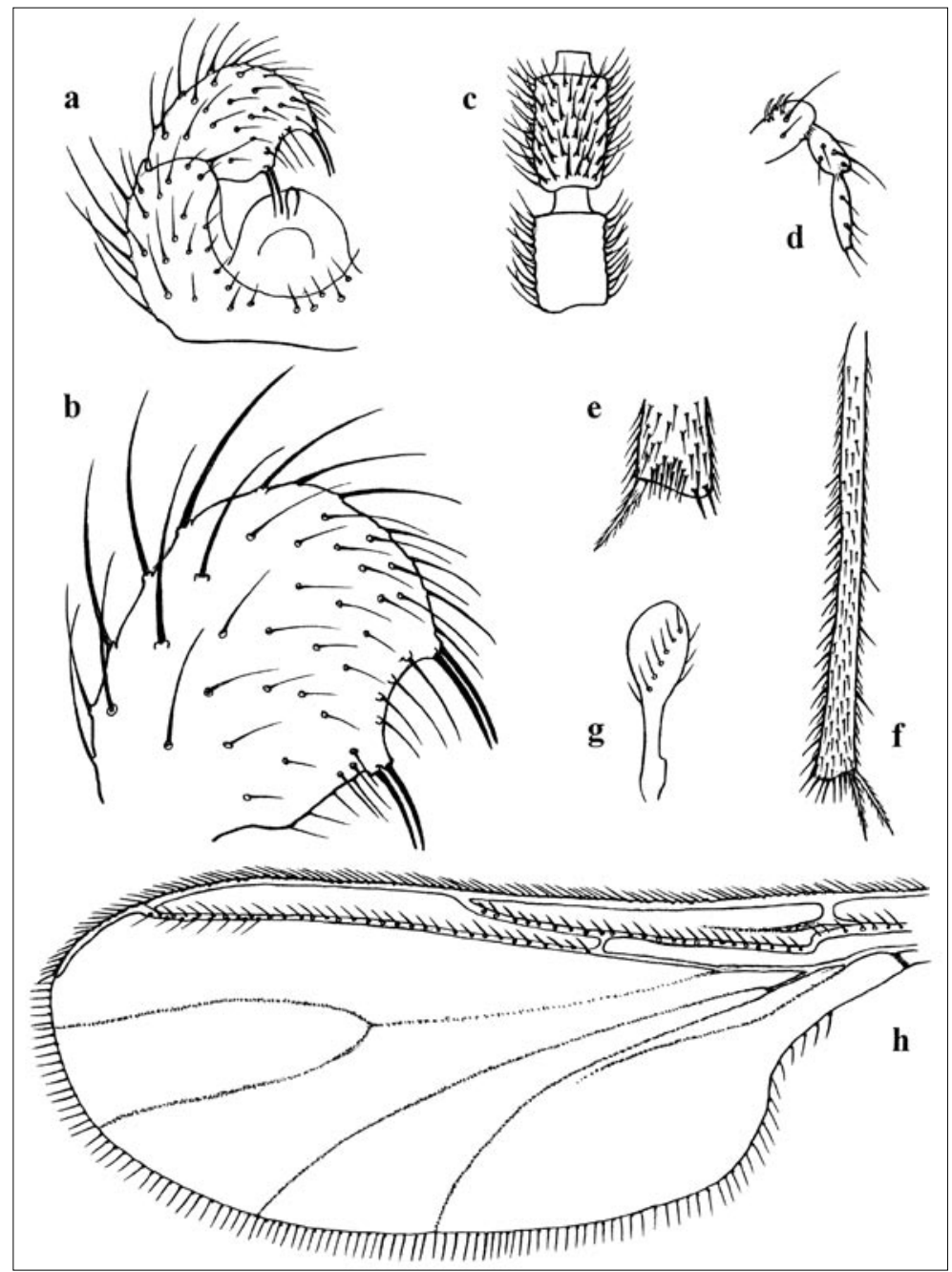

Fig. 3: Cratyna (Cratyna) tempestiva sp. $\mathrm{n}$. $\dagger$. a) hypopygium, right side, $\mathrm{x} 200$; b) gonostylus, $\mathrm{x}$ 400; c) flagellomeres 3-4; d) palpus; e) tip of fore tibia; f) hint tibia; g) halter, x 200; h) wing, x 80. 


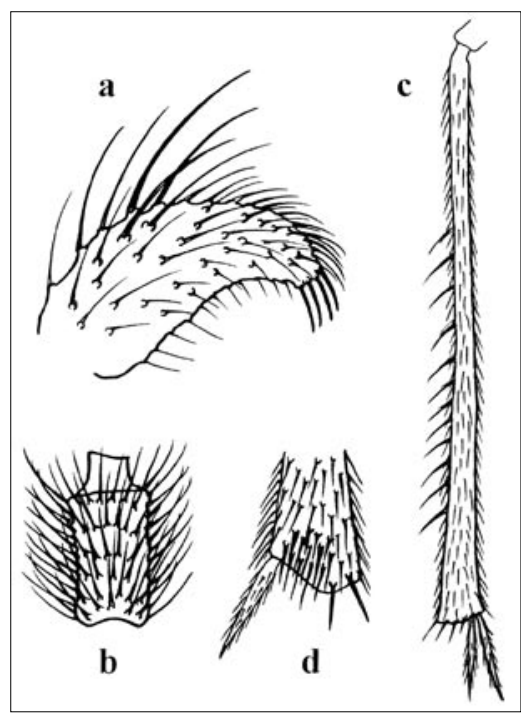

Fig. 4: Cratyna villosoantennata sp. n. $\dagger$. a) gonostylus; b) flagellomere 4; c) hint tibia; d) tip of fore tibia, all x 200 .

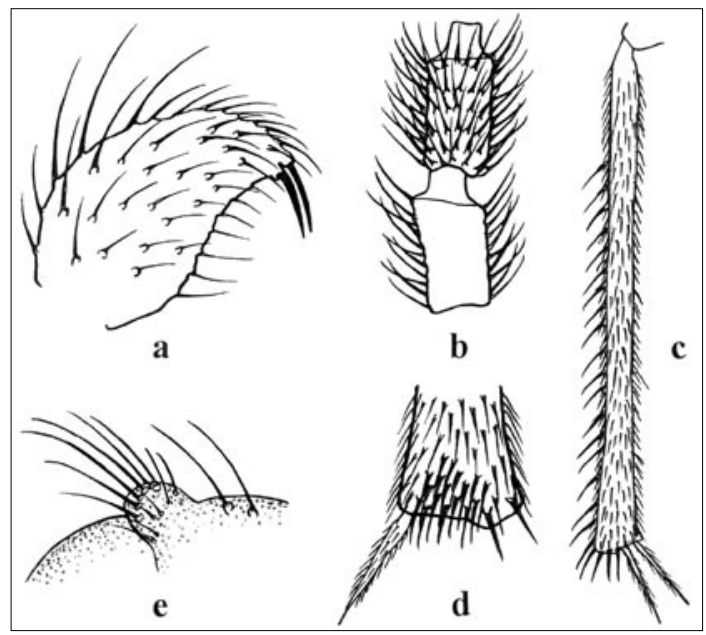

Fig. 5: Cratyna interposita sp. n. †. a) gonostylus; b) flagellomeres 3-4; c) hint tibia; d) tip of fore tibia; e) dorsal part of thorax, lateral view, x 200 . 


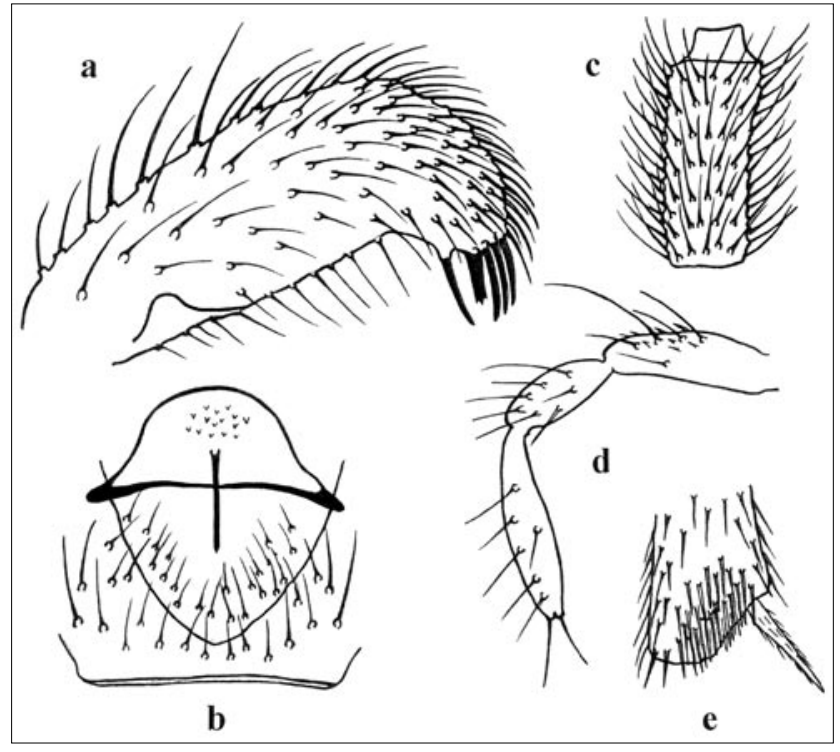

Fig. 6: Archicratyna zimbabwae sp. n. a) gonostylus, $x 400$; b) ventral base of hypopygium; c) flagellomere 4; d) palpus; e) tip of fore tibia, x 200 .

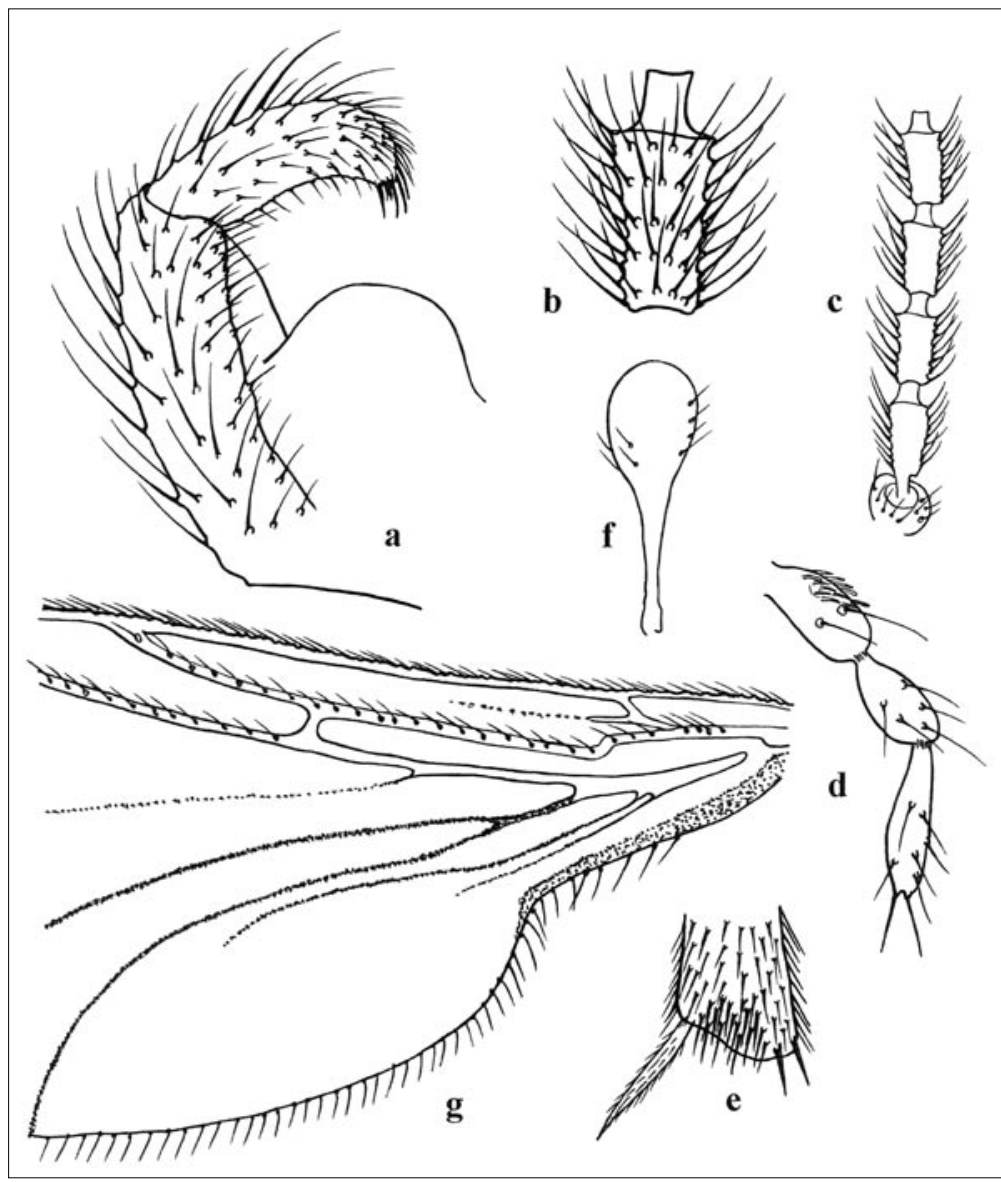

Fig. 7: Archicratyna arcana sp. n. †. a) hypopygium, right side; $\mathbf{b}$ ) flagellomere 4; c) basal part of antennae with pedicel and flagellomeres $1-4 ; \mathrm{d}$ ) palpus; e) tip of fore tibia; $f$ ) halter, x 200; g) basal part of wing, $x 80$. 


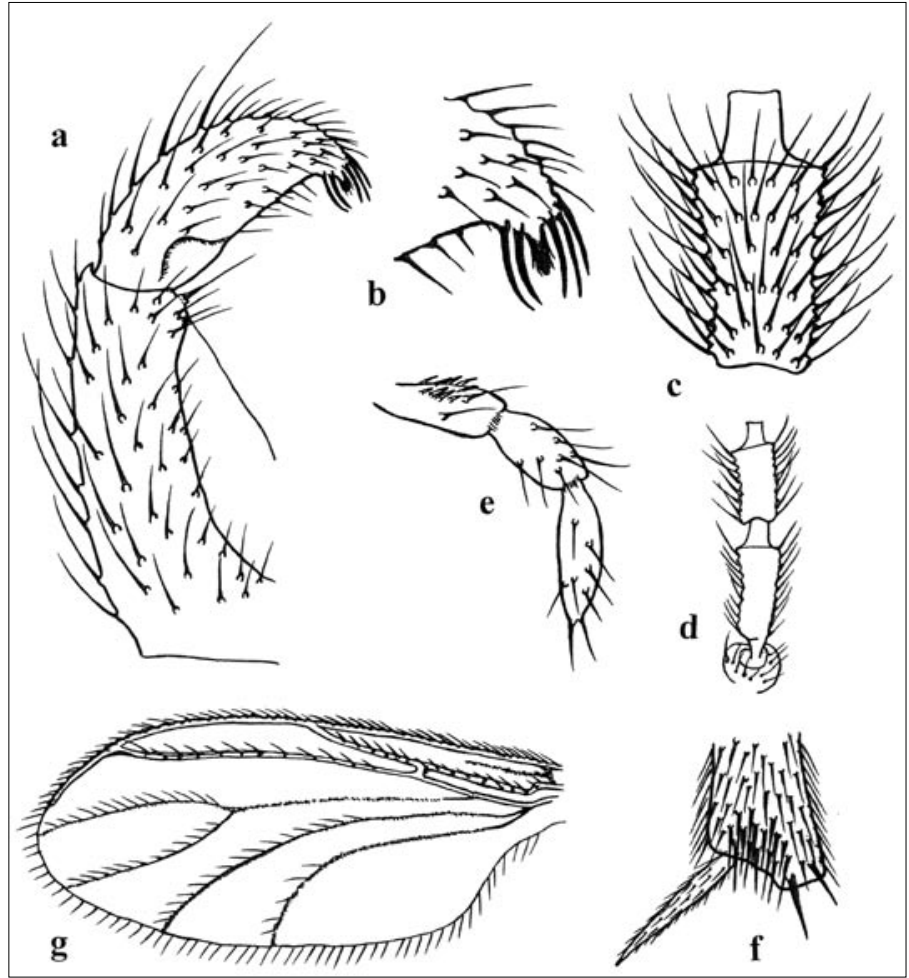

Fig. 8: Archicratyna trichoarcana sp. n. $\dagger$. a) hypopygium, right side, $x$ 200; b) tip of gonostylus, $\mathrm{x} 400$; c) flagellomere 4, $\mathrm{x}$ 200 ; d) basal part of antennae with pedicel and flagellomeres $1-2, \mathrm{x} 80$; e) palpus; f) tip of fore tibia, x 200, g) wing, $x 30$.

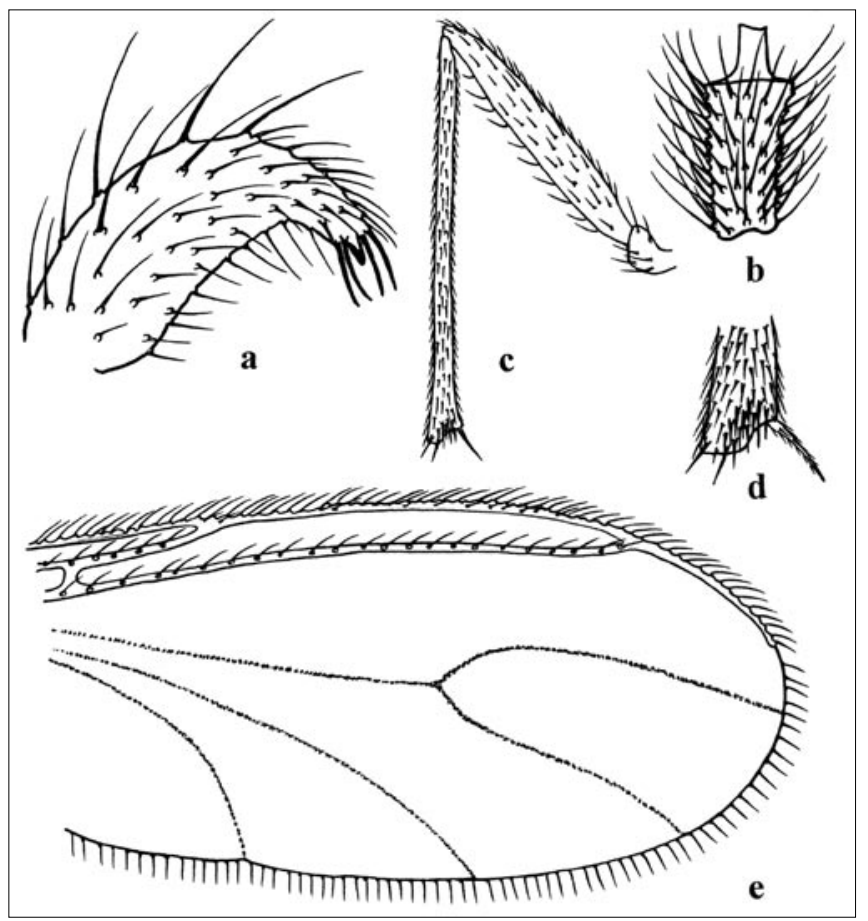

Fig. 9: Archicratyna subarcana sp. n. $\dagger$. a) gonostylus; b) flagellomere 4; c) femur and tibia of fore leg; d) tip of fore tibia, x 200; e) distal part of wing, $\mathrm{x} 80$. 


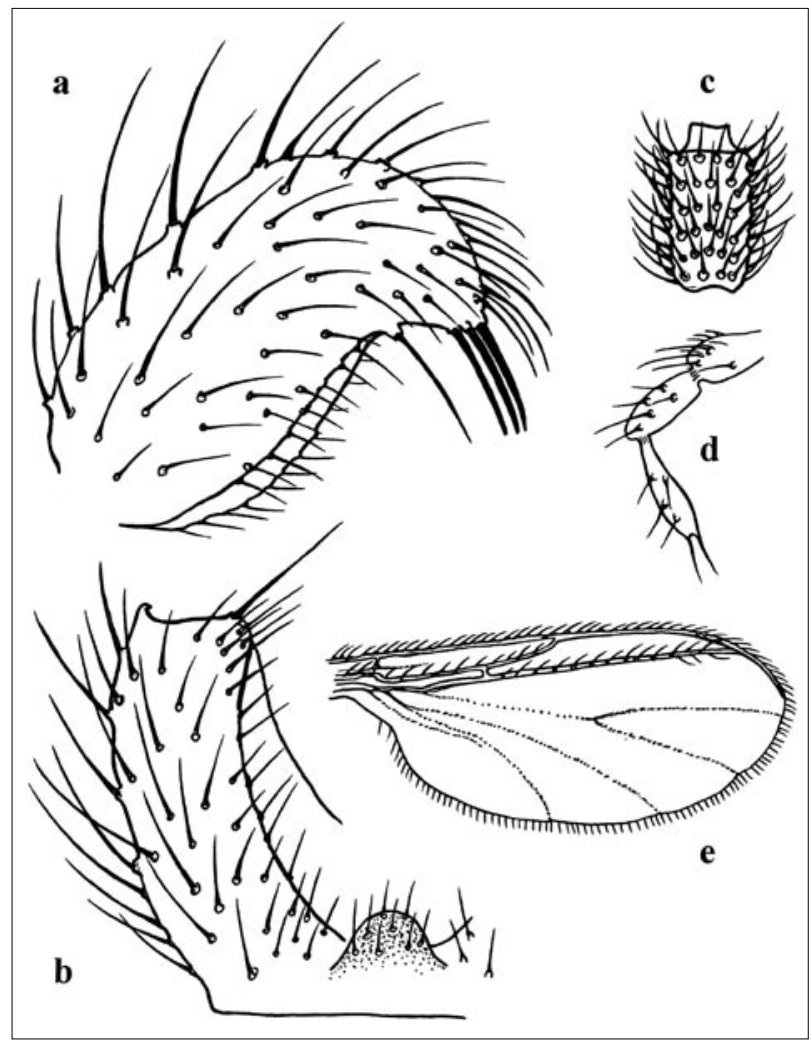

Fig. 10: Chaetosciara obsoleta sp. $\mathrm{n} . \dagger$. a) gonostylus, $\mathrm{x} 400$; $\mathrm{b}$ ) ventral base of hypopygium; c) flagellomere 4; d) palpus, x 200; e) wing, x 30 . 


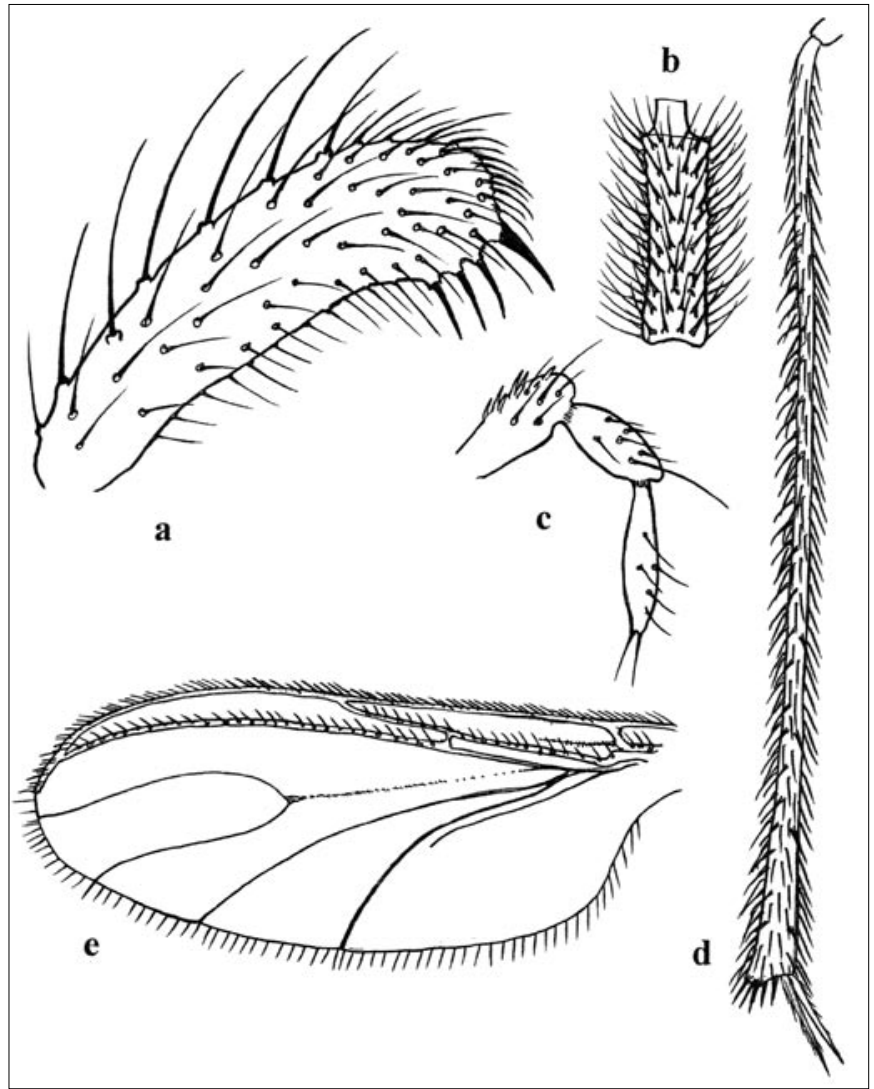

Fig. 11: Bradysiopsis repentina sp. $\mathrm{n} . \dagger$. a) gonostylus, $\mathrm{x}$ 400; b) flagellomere 4; c) palpus; d) hint tibia; $\mathrm{x}$ 200; e) wing, $x 30$.

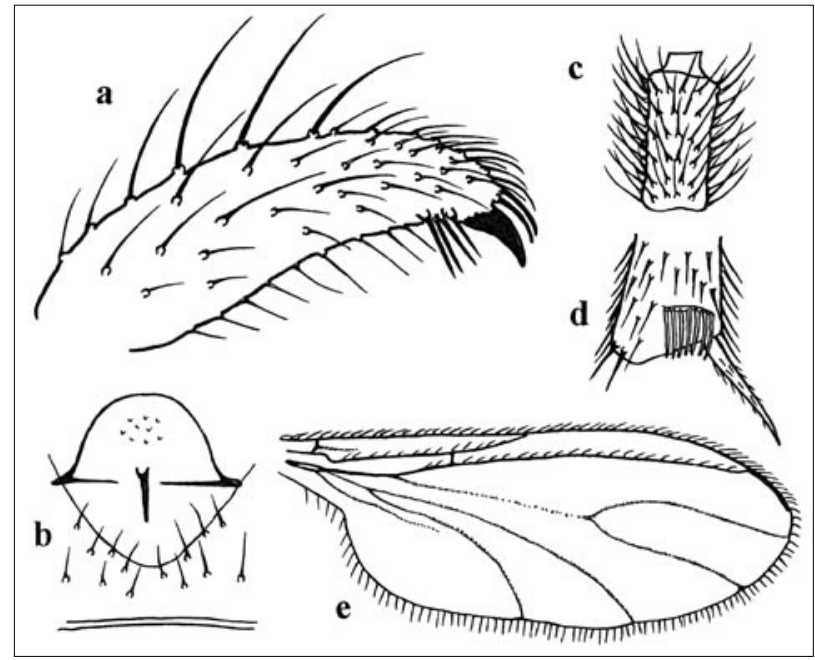

Fig. 12: Bradysia antiqua sp. $n . \dagger$. a) gonostylus, $x$ 400; b) ventral base of hypopygium; c) flagellomere 4; d) tip of fore tibia, $x 200$; e) wing, $x 30$. 


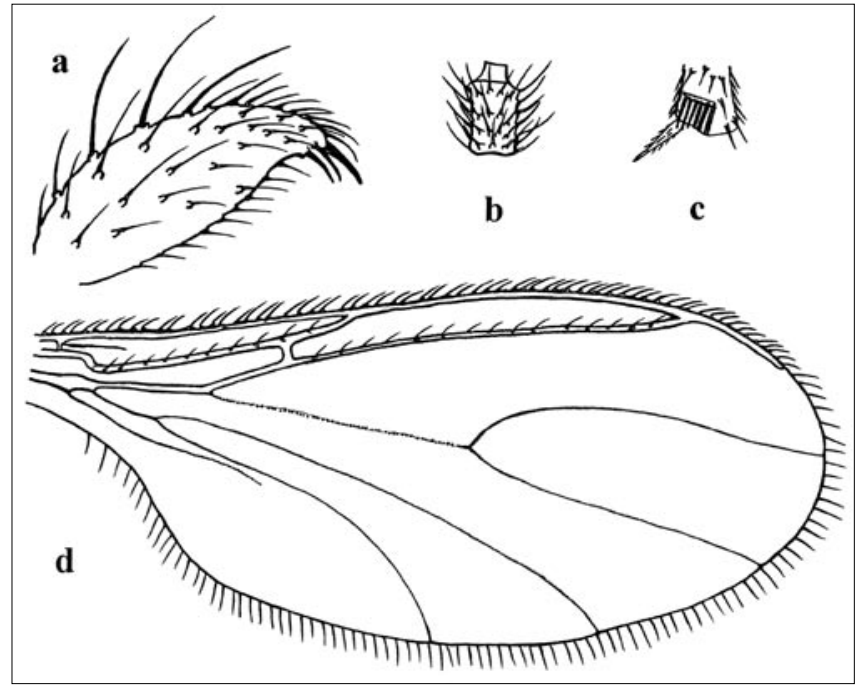

Fig. 13: Bradysia exoleta sp. $\mathrm{n} . \dagger$. a) gonostylus, $\mathrm{x} 400$; b) flagellomere 4; c) tip of fore tibia, $\mathrm{x} 200$; d) wing, $x 80$.

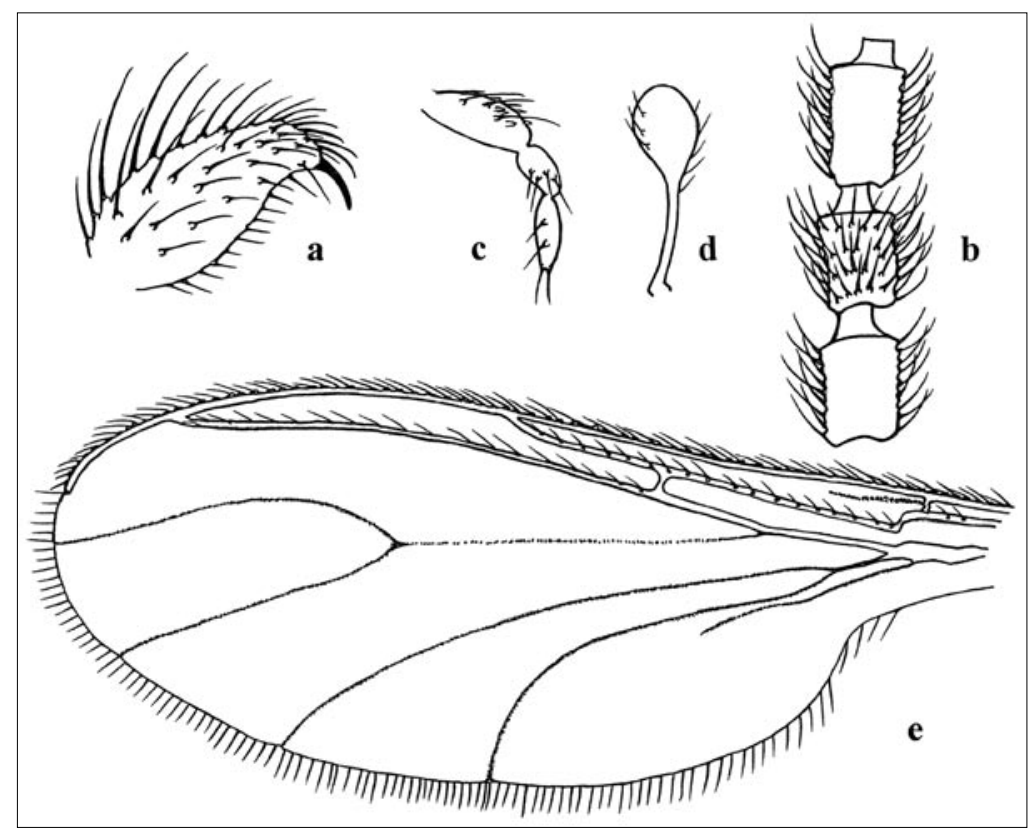

Fig. 14: Bradysia dimidiata sp. $\mathrm{n} . \dagger$. a) gonostylus, $\mathrm{x} 400$; b) flagellomere 3-5; c) palpus; d) halter, x 200; e) wing, $x 80$. 


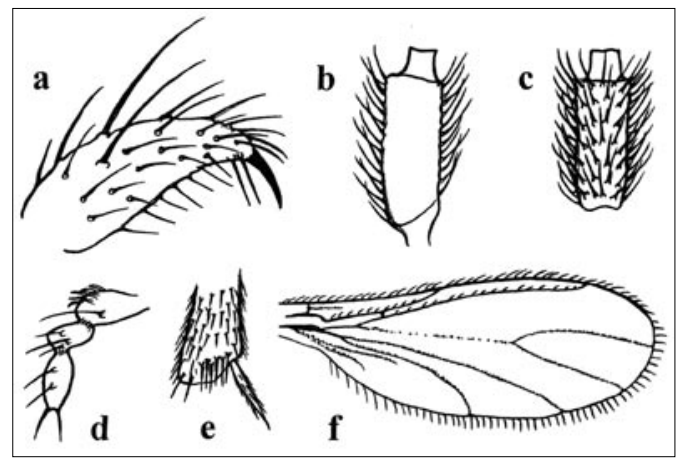

Fig. 15: Corynoptera pristina sp. n. †. a) gonostylus, x 400; b) flagellomere 1; c) flagellomere 4; d) palpus; e) tip of fore tibia, x 200; f) wing, x 30 .

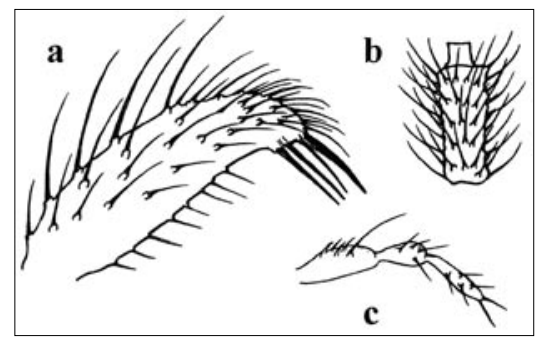

Fig. 16: Corynoptera prisca sp. n. †. a) gonostylus, x 400; b) flagellomere 4; c) palpus, $\mathrm{x} 200$.

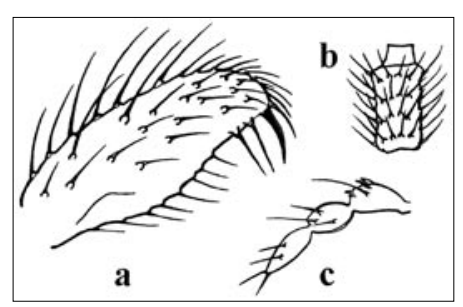

Fig. 17: Corynoptera iocosa sp. n. $\dagger$. a) gonostylus, $x 400$; b) flagellomere 4; c) palpus, $\mathrm{x} 200$.

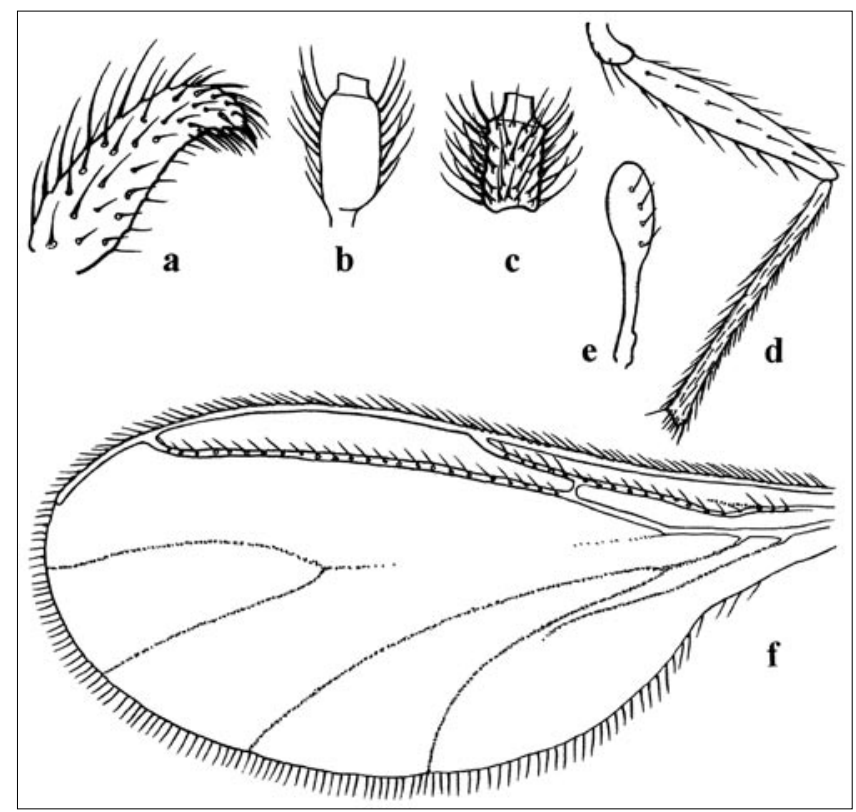

Fig. 18: Epidapus microspinus sp. $n$. $\dagger$. a) gonostylus, $\mathrm{x} 400$; b) flagellomere 1; c) flagellomere 4; d) femur and tibia of fore leg; e) halter, x 200; f) wing, x 80 . 


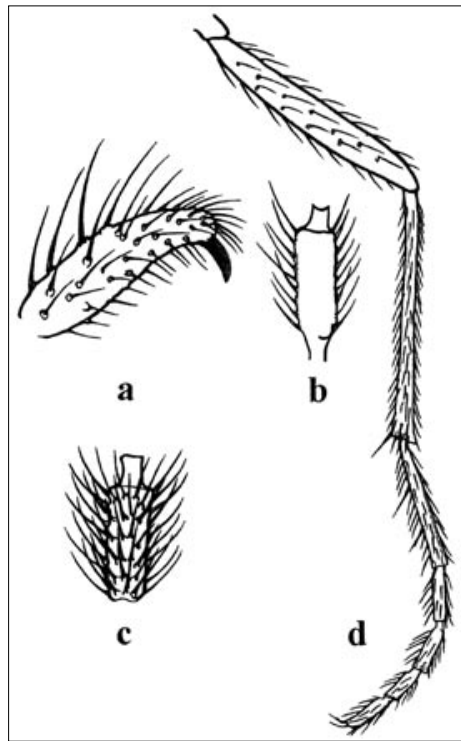

Fig. 19: Epidapus macrospinatus sp. $\mathrm{n} . \dagger$. a) gonostylus, $\mathrm{x} 400$; b) flagellomere 1; c) flagellomere 4; d) fore leg, x 200.

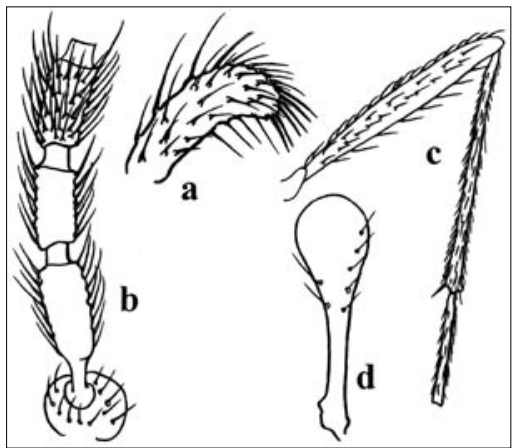

Fig. 20: Epidapus adstrictosetus sp. n. †. a) gonostylus, $x$ 400; b) basal part of antennae with pedicel and flagellomeres 1-3; c) femur, tibia and tarsalia 5 of fore leg; d) halter, x 200.

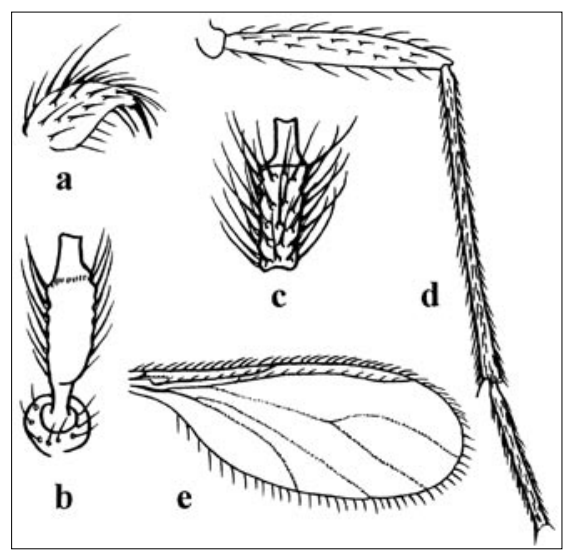

Fig. 21: Epidapus longisetus sp. $\mathrm{n} . \dagger$. a) gonostylus, $\mathrm{x} 400$; b) pedicel and flagellomere 1; c) flagellomere 4; d) femur, tibia and tarsalia 5 of fore leg, x 200; e) wing, x 30 . 